\title{
Seasonal patterns of nitrogen fixation and denitrification in oceanic mangrove habitats
}

\author{
Rosalynn Y. Lee, Samantha B. Joye* \\ Department of Marine Sciences, University of Georgia, Athens, Georgia 30602-3636, USA
}

\begin{abstract}
Mangrove peat soils are home to a variety of microbial communities that may play a vital role in system-level elemental cycling. We examined rates of nitrogen fixation and denitrification in benthic microbial mats on Twin Cays, Belize, a pair of oceanic mangrove islands. A tree-height gradient across the islands created distinct habitats for benthic microbes. Seawater flushing of the benthos and tree height decreased landward from tall, dense trees on the island fringe through a transition zone of high elevation and intermediate tree heights. In the center of the islands, microbial mats with dense communities of cyanobacteria and purple sulfur bacteria covered the benthic surface of shallow ponds and around dwarf trees. Wet-dry seasonality, tidal cycles and elevation controlled the extent of mat exposure to desiccation and UV radiation. Nitrogen fixation was controlled primarily by the sensitivity of nitrogenase to oxygen inhibition, whereas denitrification was limited by oxidant (nitrate) availability. Diel patterns of nitrogen fixation varied with the type of cyanobacteria dominant in each mat. Dissolved inorganic nitrogen concentration influenced both nitrogen fixation and denitrification rates. Redox conditions contributed to variability in mat nitrogen fixation and denitrification response to nutrient addition, while dissolved organic carbon did not. Microbial mat nitrogen cycling likely contributes to the nutrient (nitrogen and phosphorus) limitation patterns observed in the mangrove trees; in dwarf habitats, mats serve as a source of nitrogen via nitrogen fixation, while in fringe and transition habitats, mats compete with the trees for nitrogen via denitrification.
\end{abstract}

KEY WORDS: Microbial mat - Cyanobacteria · Mangrove · Nitrogen fixation · Denitrification · Desiccation Resale or republication not permitted without written consent of the publisher

\section{INTRODUCTION}

Microbial mats proliferate in shallow aquatic ecosystems, including tidal flats and coastal and hypersaline lagoons because of their ability to tolerate extremes in salinity, desiccation, temperature and ultraviolet radiation (Stal 2000). Benthic microbial mats are also found in intertidal mangrove environments (Potts 1980, Mann \& Steinke 1993, Paling \& McComb 1994). Mats may flourish especially in 'dwarf' mangrove forests, because the low stature and thin canopies of the trees allow abundant photosynthetically-active radiation (PAR) to reach the sediment surface (R. Y. Lee \& S. B. Joye unpubl.).

Microbial mats play an active role in the nutrient status of benthic environments. Nutrient limitation in marine environments is due primarily to the lack of nitrogen (N) (Howarth 1988). At oligotrophic offshore mangrove islands, inputs of $\mathrm{N}$ depend upon atmospheric and oceanic inputs and dinitrogen $\left(\mathrm{N}_{2}\right)$ fixation which are balanced by loss via denitrification, export and burial. High rates of $\mathrm{N}_{2}$ fixation in mangrove environments have been documented in association with leaf litter, pneumatophores, and soils (Holguin et al. 2001). In contrast, denitrification rates in mangrove habitats are considered a negligible part of the $\mathrm{N}$ budget (Rivera-Monroy \& Twilley 1996, Kristensen et al. 1998). However, neither of these processes has been well studied in benthic mats in mangrove forests.

To quantify the role of benthic microbial mats in oceanic mangrove ecosystem $\mathrm{N}$ cycling, we investigated spatial and temporal dynamics of $\mathrm{N}_{2}$ fixation and 
denitrification with respect to daily and seasonally varying physical and chemical environmental forces. Diel cycles of photosynthetically active radiation (PAR) influence $\mathrm{O}_{2}$ concentration dynamics due to variations in $\mathrm{O}_{2}$ production and consumption, and $\mathrm{O}_{2}$ concentration may alter activity of the $\mathrm{O}_{2}$-sensitive nitrogenase enzyme and influence facultative denitrifying microbes. Daily and seasonal changes in environmental parameters such as temperature, tidal height, and desiccation also affect patterns of $\mathrm{N}$ cycling. Substrates such as organic carbon, nitrogen, phosphorus and trace metals may limit microbial activity in oligotrophic oceanic mangrove habitats, and additions of these nutrients may alter rates of $\mathrm{N}_{2}$ fixation and denitrification. Our objectives were to document the primary effects of $\mathrm{N}$ availability and tidal hydration on daily and seasonal patterns of $\mathrm{N}$ cycling in oceanic mangrove microbial mats and to demonstrate the adaptation of these mats to a dynamic environment. We hypothesized that microbial mats play a key role in the productivity of oceanic mangrove islands, and that microbial mats may contribute to the previously documented system-scale patterns of nutrient limitation (Feller et al. 2003).

\section{MATERIALS AND METHODS}

Study site. Twin Cays is a well-described 92 ha pair of peat-based tropical oceanic mangrove islands located off the coast of Belize (McKee et al. 2002, Feller et al. 2003). The primary vegetation on the islands is Rhizophora mangle, and its tree height gradient generates distinct benthic habitats delineated by gradients in benthic-surface available PAR, tidal inundation, water table height, porewater salinity and porewater sulfide concentrations. The semidiurnally inundated 'fringe' habitat on the edge of the islands consists of tall $(5$ to $7 \mathrm{~m}$ ) R. mangle. Benthic-surface light availability is low in fringe habitats due to high tree basal area and thick canopies. Landward vegetation shifts to a 'transition' habitat of intermediate-height (2 to $4 \mathrm{~m}$ ) $R$. mangle mixed with Avicennia germinans and Laguncularia racemosa stands on higher elevation with infrequent flooding $\left(<50\right.$ times $\left.\mathrm{yr}^{-1}\right)$. The typically flooded interior 'dwarf' mangrove habitat is lowest in elevation and features less dense, shorter $(<1.5 \mathrm{~m})$ mangrove trees with more open canopies, resulting in high benthic surface light availability. Dwarf mangrove habitats and associated treeless lagoons comprise approximately $44 \%$ of the island area (Rodriguez \& Feller 2004) (Fig. 1). The dwarf zone is home to laminated, cyanobacteria-dominated microbial mats that vary from several $\mathrm{mm}$ up to $\mathrm{cm}$ in thickness. In contrast, the sparse benthic microbial community in the transition and fringe habitats, dominated by eukaryotic microalgae and cyanobacteria, was consistently less than $1 \mathrm{~mm}$ thick.

Like most tropical systems, Twin Cays exhibits wetdry seasonality, with rainy and slightly cooler fall and winter seasons contrasting with dry and warmer spring and summer seasons. The semidiurnal tides also ex-

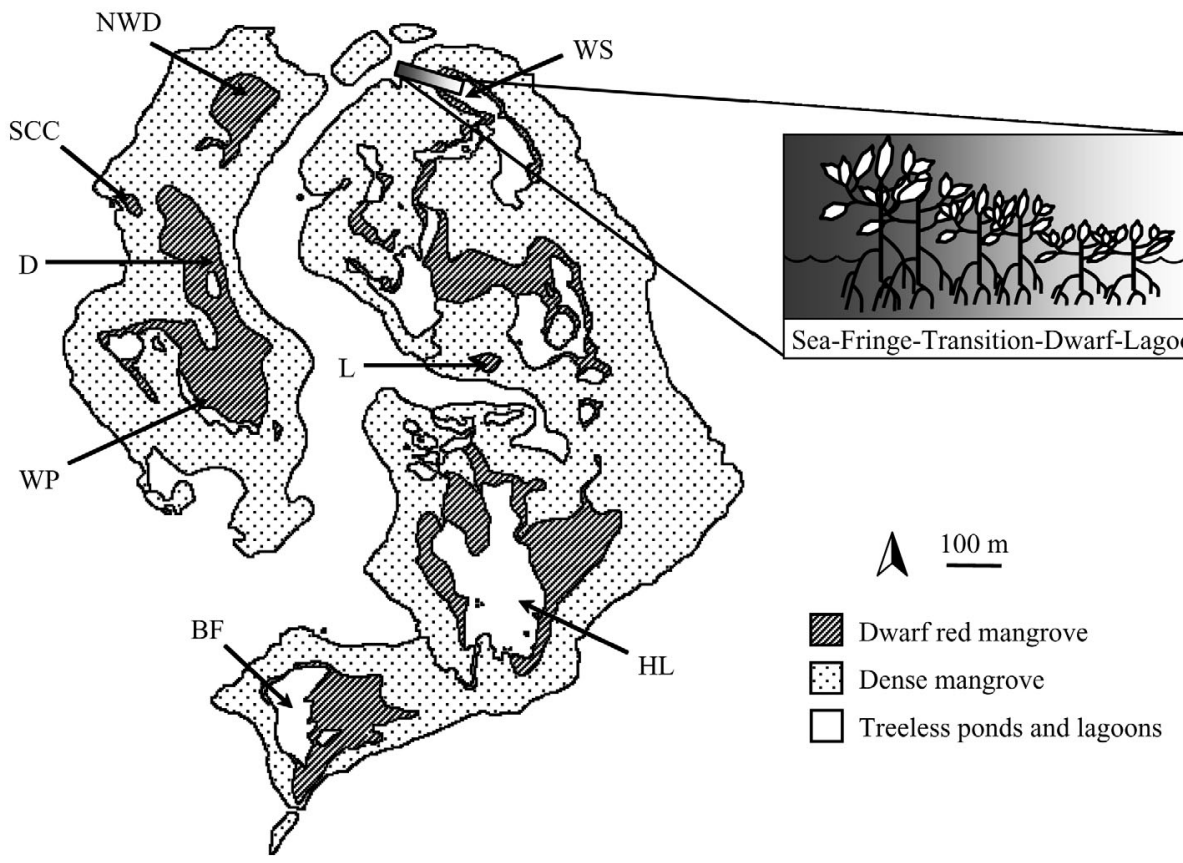

Fig. 1. Twin Cays, Belize. WS: Weather Station, L: Lair, HL: Hidden Lake, BF: Boa Flats, WP: West Pond, D: Dock, SCC: South of Clear Cut, NWD: North West Dock. Inset illustrates the tree-height gradient across a transect from the fringe through the transition to the dwarf habitat. Adapted from Feller (1996) 
hibit a seasonal cycle, with extreme low tides common in spring/summer and extreme high tides common in fall. These tidal variations affect the daily exposure/ submergence regimes of soils and microbial mats.

Spatial variation in rates of $\mathrm{N}_{2}$ fixation and denitrification was examined in fringe, transition and dwarf microbial mats from 8 sites on Twin Cays (Fig. 1). We conducted 6 field expeditions in November 2000, June and October 2001, March and September 2002, and May 2003 to examine spatio-temporal variability in N dynamics. The September, October, and November trips reflect cooler, wetter conditions. Monitoring data collected from the Smithsonian Institution's Field Station on Carrie Bow Cay (3.5 km from Twin Cays) indicated monthly solar radiation maxima of 1021 to $1168 \mathrm{~W} \mathrm{~m}^{-2}$ and average monthly rainfall of 6.7 to $12.8 \mathrm{~mm} \mathrm{~d}^{-1}$ (Opishinski 2000-2003; available at: http://web8.si.edu/belize). Low tides varied between 7 and $16 \mathrm{~cm}$ below mean sea level, and high tides varied between 28 and $30 \mathrm{~cm}$ above mean sea level. The March, May, and June trips reflect warmer, drier conditions. During these months, Carrie Bow Cay received monthly solar radiation maxima of 1149 to $1381 \mathrm{~W} \mathrm{~m}^{-2}$ and average monthly rainfall of 0.2 to $1.7 \mathrm{~mm} \mathrm{~d}^{-1}$. Low tides varied between 20 and 42 below mean sea level and high tides varied between 4 and $32 \mathrm{~cm}$ above mean sea level. June 2001 is notable among all the dates because minus tides and low rainfall resulted in severe desiccation of Twin Cays soils and microbial mats.

Environmental states. Physical and chemical parameters were investigated to characterize the benthic environment. Gradients in benthic PAR availability across fringe, transition and dwarf habitats were logged simultaneously over hours to days using a LICOR pyranometer. Surficial mat samples consisted of microbial mat and any adjacent underlying soil (peat) to a total depth of $1 \mathrm{~cm}$. Surficial mat porosity (g water per $g$ wet sample [gws]) and organic content ( $g$ per $g$ dry sample [gds]) were calculated as mass lost after $24 \mathrm{~h}$ at $60^{\circ} \mathrm{C}$ and loss-on-ignition after $24 \mathrm{~h}$ at $500^{\circ} \mathrm{C}$, respectively. Benthic chlorophyll a ( $\mathrm{chl}$ a) was monitored seasonally to evaluate photosynthetic capacity. Surface mat sub-samples $\left(1 \mathrm{~cm}\right.$ deep with a $1.03 \mathrm{~cm}^{2}$ surface area) were preserved immediately with $\mathrm{MgCO}_{3}$ and frozen. Upon return to the laboratory, chl a samples were extracted and sonicated in a $45 \%$ acetone, $45 \%$ methanol and $10 \%$ deionized water mixture, then analyzed by spectrophotometry with a correction for phaeophytin (Strickland \& Parsons 1972). Mat samples were also collected for microscopic examination and identification.

Porewater and overlying water $\mathrm{pH}$ and dissolved chemical species were monitored to quantify the conditions of the benthic nutrient and redox environment. Porewater was collected at $10 \mathrm{~cm}$ depth using a PVC piezometer. Dissolved organic carbon (DOC), inorganic and organic $\mathrm{N}\left(\mathrm{NH}_{4}{ }^{+} ; \mathrm{NO}_{3}{ }^{-}+\mathrm{NO}_{2}{ }^{-}=\mathrm{NO}_{\mathrm{x}}{ }^{-}\right.$; DON = total dissolved $\mathrm{N}[\mathrm{TDN}]-$ dissolved inorganic $\mathrm{N}$ $\left.\left[\mathrm{DIN}=\mathrm{NH}_{4}{ }^{+}+\mathrm{NO}_{\mathrm{x}}{ }^{-}\right]\right)$and phosphorus (P) $\left(\mathrm{PO}_{4}{ }^{3-} ; \mathrm{DOP}\right.$ $=$ total dissolved phosphorus [TDP] - dissolved inorganic phosphorus [DIP $\left.\left.=\mathrm{PO}_{4}{ }^{3-}\right]\right)$, sulfur $\left(\mathrm{SO}_{4}{ }^{2-}, \mathrm{H}_{2} \mathrm{~S}\right)$, reduced iron $\left(\mathrm{Fe}^{2+}\right)$ and salinity (total salts and $\mathrm{Cl}^{-}$) samples were immediately $0.2 \mu \mathrm{m}$ filtered and preserved, then stored at $4^{\circ} \mathrm{C}$. Filtered overlying water and pore water aliquots were fixed in sample to preservative ratios of 5:0.2 $\mathrm{NH}_{4}^{+}$:phenol reagent (22 ml phenol, $198 \mathrm{ml}$ ethanol, $8 \mathrm{ml}$ deionized water), 4:0.1 DOC/ $\mathrm{PO}_{4}{ }^{3-} / \mathrm{TDP} / \mathrm{Fe}^{2+} / \mathrm{Cl}^{-}$:concentrated ultrex nitric acid, and 5:0.5 $\mathrm{H}_{2} \mathrm{~S}: 20 \%$ weight/weight zinc acetate. $\mathrm{NO}_{\mathrm{x}}{ }^{-}$/ TDN samples were filter-sterilized.

All dissolved components were analyzed as soon as possible (within 3 weeks of collection). Colorimetric assays for $\mathrm{NH}_{4}{ }^{+}$(phenol hypochlorite method; Solorzano 1969), $\mathrm{PO}_{4}{ }^{3-}$ (molybdate antimony ascorbic method; Strickland \& Parsons 1972), $\mathrm{H}_{2} \mathrm{~S}$ (Cline's method; Cline 1969), and $\mathrm{Fe}^{2+}$ (ferrozine method; Stookey 1970) were conducted with a Shimadzu ${ }^{\circledR}$ UV-1601 spectrophotometer. DOC was measured using high temperature combustion and infrared $\mathrm{CO}_{2}$ detection in a Shimadzu ${ }^{\circledR}$ TOC-5000 Total Organic Carbon analyzer. $\mathrm{NO}_{\mathrm{x}}{ }^{-}$was measured on an Antek ${ }^{\circledR} 745$ Nitrate/ Nitrite Reducer (vanadium reduction assembly) inline with an Antek $^{\circledR} 7050$ chemiluminescent nitric oxide detector (Álvarez-Salgado \& Miller 1998). TDN was analyzed by high temperature combustion in a Shimad$\mathrm{zu}^{\circledR}$ TOC-5000 inline with an Antek ${ }^{\circledR} 7020$ chemiluminescent nitric oxide detector. TDP was combusted and acid hydrolyzed (Solorzano \& Sharp 1980) then analyzed spectrophotometrically as $\mathrm{PO}_{4}{ }^{3-}$. $\mathrm{Cl}^{-}$was quantified using ion chromatography (Dionex ${ }^{\circledR}$ DX500).

Diel experiments. Diel experiments were conducted to examine fluctuations in rates of $\mathrm{N}_{2}$ fixation and denitrification in relation to hourly changes in solar flux, which drive variations in rates of oxygenic photosynthesis and thus porewater $\mathrm{O}_{2}$ concentration (Joye \& Lee 2004, Lee \& Joye unpubl.). Rates of $\mathrm{N}_{2}$ fixation and denitrification were measured contemporaneously using the acetylene reduction and acetylene block techniques, respectively (Joye \& Paerl 1994). To convert acetylene reduction rates to $\mathrm{N}_{2}$ fixation rates, we assumed a conversion factor of $4: 1 \mathrm{C}_{2} \mathrm{H}_{2}: \mathrm{N}_{2}$ reduced (Postgate 1982).

Individual incubations (time points) during diel experiments spanned 4 to $6 \mathrm{~h}$ intervals over 24 to $36 \mathrm{~h}$. For each time point, sub-samples of the surface mat ( $1 \mathrm{~cm}$ deep with a $1.03 \mathrm{~cm}^{2}$ surface area) were placed into $20 \mathrm{ml}$ serum vials containing $10 \mathrm{ml}$ of GF/Ffiltered site-specific overlying water (GF/F OLW). Triplicate samples were included for each treatment. Treatments included: light, dark, light plus $\mathrm{NO}_{3}^{-}$ 
$(1 \mathrm{mM})$ and glucose $(2 \mathrm{mM})$, dark plus $\mathrm{NO}_{3}{ }^{-}(1 \mathrm{mM})$ and glucose $(2 \mathrm{mM})$, and light plus 3-(3,4 dichlorophenyl)-1,1 dimethylurea (DCMU; $10 \mu \mathrm{M})$, an inhibitor which blocks photosystem-II (PS-II), the $\mathrm{O}_{2}$ producing step of photosynthesis. Samples were incubated under natural light and temperature regimes.

Additional experiments were used to identify shortterm (hourly timescale) nutrient controls on $\mathrm{N}_{2}$ fixation and denitrification, including day and night incubations with amendments of $\mathrm{NH}_{4}{ }^{+}(0.1,0.5,1 \mathrm{mM}), \mathrm{NO}_{3}{ }^{-}$ $(0.1,0.5,1 \mathrm{mM})$, glucose $(0.5,1,2 \mathrm{mM})$, acetate $(2 \mathrm{mM})$, and lactate $(2 \mathrm{mM})$ under light and dark conditions.

Bioassay experiments. Longer-term (days-long timescale) controls on $\mathrm{N}_{2}$ fixation and denitrification were examined in bioassay experiments. Triplicate $5 \times 5 \mathrm{~cm}^{2}$ by $1 \mathrm{~cm}$ deep mat sections were incubated in individual plastic tubs (Rubbermaid ${ }^{\circledR} 3870$ ) under control (no addition) and treatment (nutrients added) conditions. Mat sections were submerged in $250 \mathrm{ml}$ of GF/F OLW. Treatments included additions of the following nutrients to the GF/F OLW: $\mathrm{NH}_{4}{ }^{+}(0.1,0.5,1 \mathrm{mM}), \mathrm{NO}_{3}{ }^{-}(0.1$, $0.5,1 \mathrm{mM}), \mathrm{NH}_{4}{ }^{+}$plus $\mathrm{NO}_{3}{ }^{-}\left(0.05 \mathrm{mM} \mathrm{NH}_{4}{ }^{+}\right.$and $\left.0.1 \mathrm{mM} \mathrm{NO}_{3}{ }^{-}\right), \mathrm{PO}_{4}{ }^{3-}(0.01 \mathrm{mM})$, glucose $(0.5,1,2 \mathrm{mM})$, acetate $(1 \mathrm{mM})$, lactate $(1 \mathrm{mM})$, sequestrine-complexed iron $(7.2 \mu \mathrm{M})$, SL-8 trace metal solution (Fe:Zn:Mn:Co: $\mathrm{Cu}: \mathrm{Ni}: \mathrm{Mo}=$ 7.5:0.5:0.5:0.8:0.1:0.1:0.1 $\mu \mathrm{M}_{i}$ Atlas 1995), and a vitamin solution $(0.1 \%$ Vitamix containing biotin, thiamine, $\mathrm{B}_{12}$, nicotinamide, folic acid, Ca pantothenate, riboflavin; Lidstrom 1988). After nutrient incubation under natural light and temperature regimes for $72 \mathrm{~h}, \mathrm{~N}_{2}$ fixation and denitrification rates under light and dark conditions were determined as described above.

Hydration experiments. Under the extremely dehydrated surface mat conditions of June 2001, experiments were conducted to elucidate the effects of desiccation and rehydration on daytime $\mathrm{N}_{2}$ fixation and denitrification rates. To investigate short-term (hourly) effects of rehydration, desiccated microbial mats were incubated as described above $\left(1 \mathrm{~cm}\right.$ deep $\times 1.03 \mathrm{~cm}^{2}$ surface area sub-samples in $20 \mathrm{ml}$ vials), but under a suite of different conditions: dry (no water addition), moist (with 3 drops of GF/F OLW), wet (with $10 \mathrm{ml}$ of GF/F OLW), wet/dry (dry incubation following 20 min of rehydration with GF/F OLW), and wet/moist (incubation with 3 drops of GF/F OLW after 20 min of rehydration with GF/F OLW). Longer-term effects of rehydration and desiccation were investigated in dehydrated and moist mats after 1 to $5 \mathrm{~d}$ of mat moisture content manipulation. Dehydrated (dry) mats were rehydrated (i.e. submerged in GF/F OLW) for 1, 2, or $5 \mathrm{~d}$ or alternately rehydrated and dried (i.e. submerged in GF/F OLW on the first day, removed from OLW on the second day, submerged on the third day, etc.) over $5 \mathrm{~d}$. Likewise, moist (wet) microbial mats were desiccated (i.e. air exposed) for 1, 2, or
$5 \mathrm{~d}$ or alternately dried and rehydrated (i.e. exposed on the first day, submerged on the second day, exposed on the third day, etc.) over $5 \mathrm{~d}$. Longer-term rehydration incubations were conducted in wet ( $10 \mathrm{ml}$ of GF/F OLW) and dry (no water addition) incubations under helium as well as air headspaces to differentiate the effects of oxygenation from dehydration.

\section{RESULTS}

Each of the study sites contained diverse assemblages of cyanobacteria, including filamentous species (e.g. Oscillatoria, Lyngbya, Microcoleus, Phormidium, Johannesbaptistia, Spirulina and heterocystous Nodularia and Scytonema spp.) and unicellular species (e.g. Aphanocapsa, Chroococcus, Gloeocapsa spp.), and composition varied seasonally (Joye \& Lee 2004). Heterocystous cyanobacteria (HC) communities were present at dwarf mangrove habitats in November 2000 (at site WS), June 2001 (WS), March 2002 (NWD and WS), September 2002 (L and WS), and May 2003 (WS), while only non-heterocystous cyanobacteria (NHC) were present in all other mats. The cyanobacterial layer in dwarf and pond habitats was usually overlain by a diffuse film of pennate diatoms and underlain by a multi-mm thick layer of purple sulfur bacteria. Photosynthetic biomass in fringe and transition microbial mats was similar, ranging

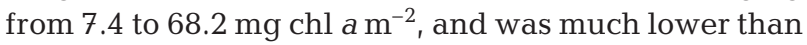
that observed in dwarf and pond mats (20.9 to $499.9 \mathrm{mg}$ $\mathrm{chl} a \mathrm{~m}^{-2}$ ) (Table 1). Porosity and organic content of the surficial mat from all habitats was similar. PAR reaching the benthic surface was not strictly inversely-related to chl $a$, but decreased steadily from dwarf through transition to fringe habitats.

Overlying and porewater chemistry varied seasonally and spatially. Fringe habitats were consistently flushed semi-diurnally with oligotrophic ocean water, while transition habitats were typically exposed to air, preventing the accumulation of reduced chemical species on short (daily) time scales. During the wet season, dwarf habitats were flushed so that pond water composition was 35 to $37 \%$ salt, $7.98 \mathrm{pH}, 3 \mu \mathrm{M} \mathrm{NH}_{4}{ }^{+}$, and less than $1 \mu \mathrm{M} \mathrm{NO}_{\mathrm{x}}{ }^{-}, \mathrm{PO}_{4}{ }^{3-}, \mathrm{Fe}^{2+}$, and $\mathrm{H}_{2} \mathrm{~S}$ (similar to transition and fringe habitat overlying waters) (data not shown). During the dry season and under the influence of extreme low tides, dwarf habitats were flooded less frequently, resulting in increased overlying water salinities $(40 \%)$ and an order of magnitude higher $\mathrm{NH}_{4}{ }^{+}$concentrations $(30 \mu \mathrm{M})$ (data not shown).

Throughout the year, average porewater salinities (10 $\mathrm{cm}$ beneath mats) were slightly hypersaline and reflected tidal inundation regimes, with maximal salinities $(49.5 \%)$ in elevated transition soils, similar to the salinities observed in poorly flushed dwarf soils. Fringe 
Table 1. Mat and soil characteristics of Twin Cays fringe, transition, and dwarf habitats averaged over all seasons. PAR ratio: PAR at benthic surface relative to dwarf habitat PAR between 08:00 and 15:00 $\mathrm{h}$; standard deviations in parentheses

\begin{tabular}{|c|c|c|c|}
\hline Characteristic & $\begin{array}{l}\text { Fringe } \\
\text { habitat }\end{array}$ & $\begin{array}{c}\text { Transition } \\
\text { habitat }\end{array}$ & $\begin{array}{l}\text { Dwarf } \\
\text { habitat }\end{array}$ \\
\hline PAR ratio & $0.34(0.17)$ & $0.69(0.69)$ & $1.00(0.00)$ \\
\hline $\mathrm{Chl} \mathrm{a}\left(\mathrm{mg} \mathrm{m}^{-2}\right)$ & $28.7(6.5)$ & $30.1(14.4)$ & $114.1(70.6)$ \\
\hline Porosity ( $\mathrm{g} \mathrm{gws}^{-1}$ ) & $0.86(0.09)$ & $0.84(0.12)$ & $0.84(0.07)$ \\
\hline $\begin{array}{l}\text { Organic content } \\
\quad\left(\mathrm{g} \mathrm{gdw}^{-1}\right)\end{array}$ & $0.65(0.04)$ & $0.57(0.07)$ & $0.55(0.06)$ \\
\hline \multicolumn{4}{|c|}{ Porewater at $10 \mathrm{~cm}$ depth: } \\
\hline $\mathrm{pH}$ & $6.96(0.44)$ & $6.87(0.24)$ & $7.23(0.26)$ \\
\hline Salinity (ppt) & $36.2(3.7)$ & $41.3(7.4)$ & $39.9(4.3)$ \\
\hline $\mathrm{NH}_{4}{ }^{+}(\mu \mathrm{M})$ & $12.9(11.2)$ & $15.3(5.6)$ & $257.4(136.6)$ \\
\hline $\mathrm{NO}_{\mathrm{x}}^{-}(\mu \mathrm{M})$ & $0.9(0.6)$ & $1.0(0.5)$ & $1.3(0.7)$ \\
\hline DON $(\mu \mathrm{M})$ & $39.8(5.9)$ & $58.2(14.9)$ & $101.4(35.0)$ \\
\hline $\mathrm{PO}_{4}{ }^{3-}(\mu \mathrm{M})$ & $0.4(0.2)$ & $0.7(0.4)$ & $1.9(2.8)$ \\
\hline $\mathrm{DOP}(\mu \mathrm{M})$ & $1.6(0.9)$ & $1.5(0.8)$ & $1.6(0.4)$ \\
\hline DIN:DIP & $52.1(48.9)$ & $27.7(18.1)$ & $337.3(290.8)$ \\
\hline DON:DOP & $35.3(28.8)$ & $45.9(17.6)$ & $66.1(28.2)$ \\
\hline TDN:TDP & $27.6(5.5)$ & $36.1(6.7)$ & $133.3(67.5)$ \\
\hline $\mathrm{Fe}^{2+}(\mu \mathrm{M})$ & $0.5(0.4)$ & $1.0(0.6)$ & $3.2(3.7)$ \\
\hline $\mathrm{H}_{2} \mathrm{~S}(\mathrm{mM})$ & $0.43(0.14)$ & $0.48(0.15)$ & $1.32(1.40)$ \\
\hline DOC (mM) & $1.10(0.69)$ & $1.24(0.93)$ & $1.56(0.77)$ \\
\hline
\end{tabular}

soil porewater salinities were similar to that of overlying ocean waters (Table 1). In all soils, $\mathrm{pH}$ was between 6.87 and $7.23, \mathrm{NO}_{3}{ }^{-}, \mathrm{PO}_{4}{ }^{3-}, \mathrm{Fe}^{2+}$, and $\mathrm{DOP}$ concentrations were low $\left(<1.3 \mu \mathrm{M} \mathrm{NO}_{3}{ }^{-}, 1.9 \mu \mathrm{M} \mathrm{PO}_{4}{ }^{3-}\right.$, $3.2 \mu \mathrm{M} \mathrm{Fe}^{2+}$, and $2 \mu \mathrm{M}$ DOP), and DOC concentrations were high (1.10 to $1.56 \mathrm{mM}$ ). Porewaters were very reducing in dwarf soils, with elevated concentrations of $\mathrm{NH}_{4}{ }^{+}$(54.1 to $\left.458.7 \mu \mathrm{M}\right)$ and $\mathrm{H}_{2} \mathrm{~S}(0.44$ to $4.08 \mathrm{mM})$. Well-flushed fringe and rarely flooded transition soil porewaters were similarly less reducing with concentrations of $\mathrm{NH}_{4}{ }^{+}$and $\mathrm{H}_{2} \mathrm{~S}$ consistently below $20 \mu \mathrm{M}$ and $0.65 \mathrm{mM}$, respectively.

While DOP concentrations did not fluctuate across habitats, DON increased gradually with distance from the ocean at $39.8 \mu \mathrm{M}$ in the fringe to $101.4 \mu \mathrm{M}$ in dwarf soils, thus skewing the DON:DOP ratio. Similarly, DIP concentrations did not fluctuate across habitats, thus the DIN:DIP ratio was skewed with the same pattern as DIN concentration. In all habitats, dissolved inorganic, organic and total N:P ratios were above the Redfield ratio of 16:1 indicating excess nitrogen, especially in dwarf soils.

Diel patterns of $\mathrm{N}_{2}$ fixation and denitrification in dwarf mangrove habitats varied seasonally and across sites (Fig. 2). Within sites, $\mathrm{N}_{2}$ fixation rates varied as a
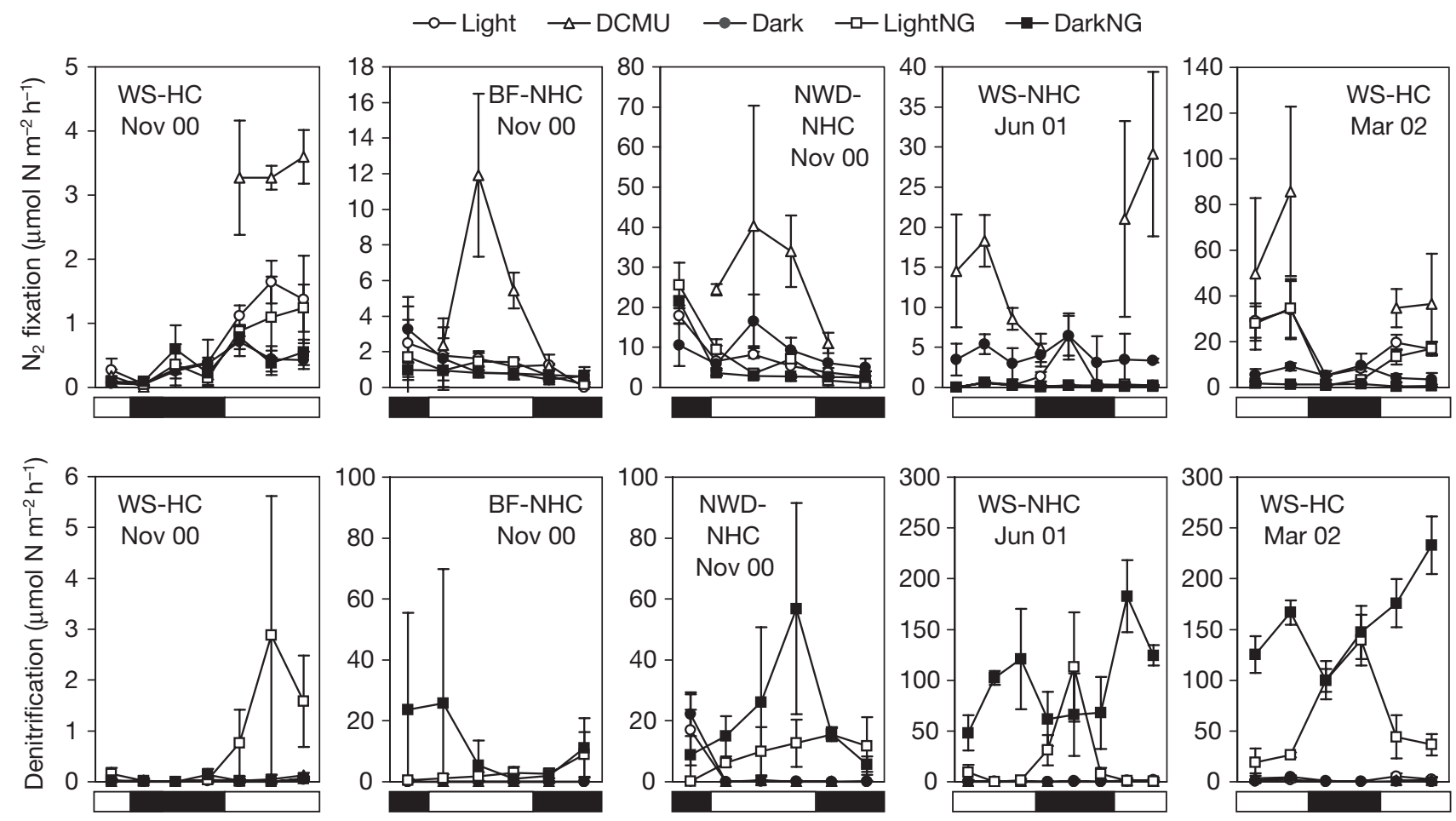

Fig. 2. $\mathrm{N}_{2}$ fixation and denitrification rates from dwarf habitat diel experiments with and without 3-(3,4 dichlorophenyl)-1,1 dimethylurea (DCMU) or nitrate $(\mathrm{N})$ and glucose $(\mathrm{G})$ amendments. Error bars are standard deviations; HC: heterocystous cyanobacterial mat; NHC: non-heterocystous cyanobacterial mat; horizontal axis bars indicate daytime $(\square)$ and nighttime (ם). WS: Weather Station; BF: Boa Flats; NWD: North West Dock 
function of community composition and PAR intensity. Mats containing HC (WS November 2000 and WS March 2002) exhibited higher daytime $\mathrm{N}_{2}$ fixation rates, while NHC mats (NWD and BF November 2000 and WS June 2001) exhibited higher nighttime rates. Daytime dark rates in $\mathrm{HC}$-containing mats were lower than light rates while daytime dark rates in NHCcontaining mats were equal to or greater than light rates. $\mathrm{N}_{2}$ fixation rates increased by an order of magnitude in DCMU-amended daylight-incubated mats relative to rates observed in unamended daylight incubations. $\mathrm{NO}_{3}{ }^{-}$and glucose addition had a slight negative effect (if any) on dwarf mat $\mathrm{N}_{2}$ fixation, which was most evident in dark treatments. In contrast, while unamended denitrification rates were negligible, $\mathrm{NO}_{3}^{-}$plus glucose addition led to significant increases in activity. Potential $\left(\mathrm{NO}_{3}{ }^{-}\right.$plus glucose amended) denitrification rates were higher during the dry season (June 2001 and March 2002) than in the wet season (November 2000). Dark potential rates were often higher than daytime light potential rates and DCMU-amended rates. Although diel patterns of potential denitrification did not mirror $\mathrm{N}_{2}$ fixation activity, higher rates of $\mathrm{N}_{2}$ fixation were often associated with higher rates of potential denitrification (note rate scales in Fig. 2).

Island-wide $\mathrm{N}_{2}$ fixation and denitrification rates exhibited minor variation across season, but differences were observed between mangrove habitats (Fig. 3). $\mathrm{NO}_{3}{ }^{-}$plus glucose addition had no significant impact on averaged island-wide $\mathrm{N}_{2}$ fixation rates in either daytime or nighttime incubations. The level of DCMUstimulation of daytime $\mathrm{N}_{2}$ fixation rates varied across season and habitat. Daytime and nighttime denitrification rates were enhanced by $\mathrm{NO}_{3}^{-}$plus glucose addition, especially in transition and fringe habitats. Unamended denitrification rates in all habitats were
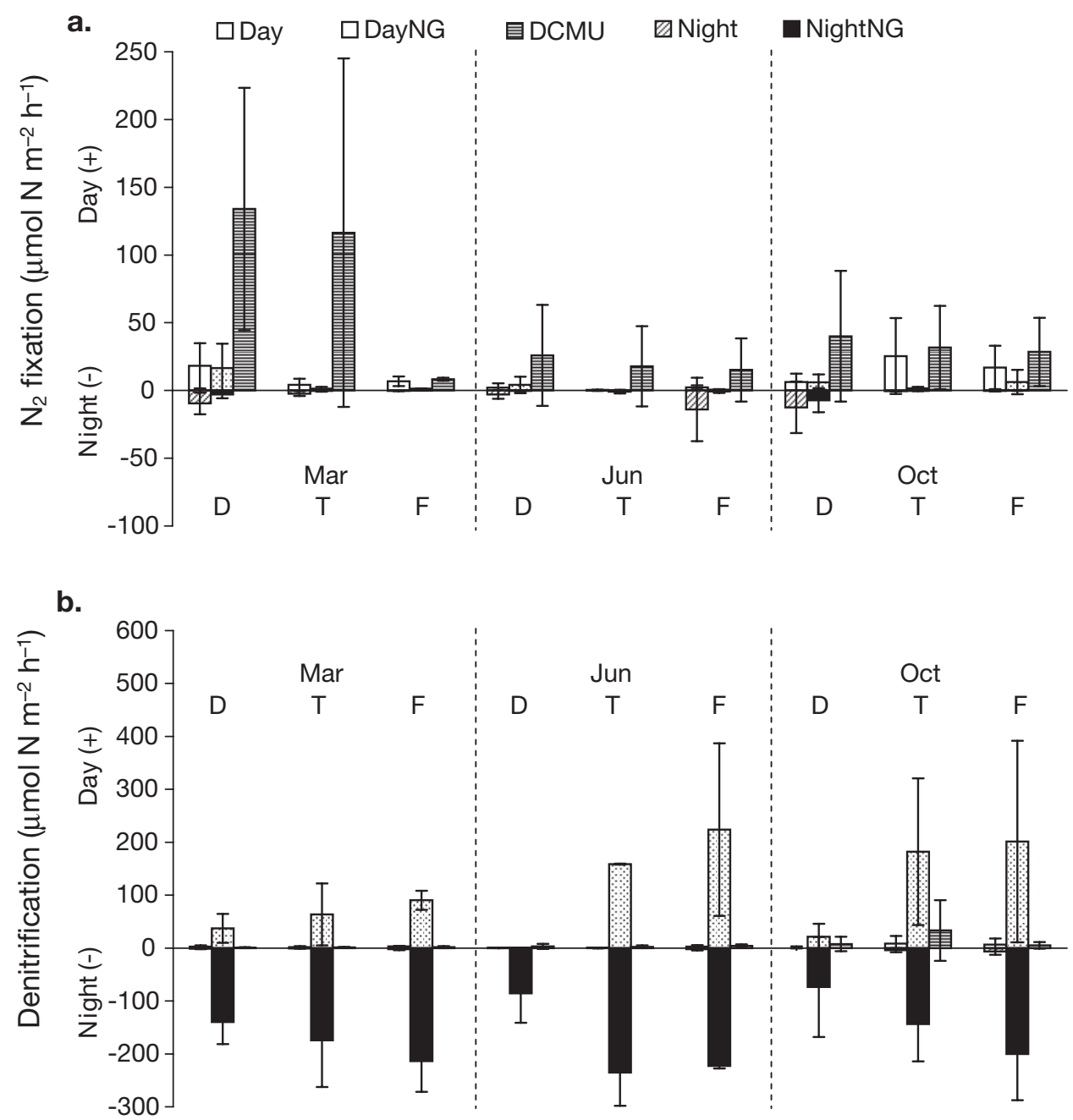

Fig. 3. Seasonal day and night (a) $\mathrm{N}_{2}$ fixation rates and (b) denitrification rates with and without 3-(3,4 dichlorophenyl)-1,1 dimethylurea (DCMU) or nitrate $(\mathrm{N})$ and glucose $(\mathrm{G})$ amendments in dwarf $(\mathrm{D})$, transition $(\mathrm{T})$, and fringe $(\mathrm{F})$ habitats. Error bars are standard deviations 
low and did not vary significantly throughout the year. Nighttime potential denitrification rates did not change with season, but March daytime potential rates were lower than those observed in June and October. Integrating daytime and nighttime rates of $\mathrm{N}_{2}$ fixation and denitrification in unamended treatments shows that $\mathrm{N}_{2}$ fixation always exceeded denitrification (Fig. 4), and rates of $\mathrm{N}_{2}$ fixation varied throughout the year across the different habitats. Trapezoidal integration of $\mathrm{N}$ cycling rates revealed that annual $\mathrm{N}$ inputs via $\mathrm{N}_{2}$ fixation were much higher than removal by denitrification, generating a net $\mathrm{N}$ input of $45.7 \mathrm{mmol} \mathrm{N}$ $\mathrm{m}^{-2} \mathrm{y}^{-1}$ (Fig. 4).

Short-term (hours-long) nutrient amendments had both negative and positive effects on rates of $\mathrm{N}$ cycling (Tables 2 \& 3). In all mangrove habitats (fringe, transition, and dwarf) and under all light conditions, denitrification rates were unaffected by $\mathrm{NH}_{4}{ }^{+}$or glucose additions. $\mathrm{NO}_{3}{ }^{-}$concentration (from 0.1 to $1 \mathrm{mM}$ ) was the main stimulus for denitrification, evidenced by low rates in glucose-only treatments and similarly high rates in $\mathrm{NO}_{3}{ }^{-}$-only and $\mathrm{NO}_{3}{ }^{-}$plus glucose treatments. Fringe and transition habitat potential denitrification rates always exceeded those in the dwarf zone, and different carbon sources (glucose, acetate or lactate) yielded similar rates.

$\mathrm{NH}_{4}{ }^{+}$and $\mathrm{NO}_{3}{ }^{-}$addition had inconsistent effects on $\mathrm{N}_{2}$ fixation in short-term nutrient amendment experiments. $\mathrm{NH}_{4}{ }^{+}, \mathrm{NO}_{3}{ }^{-}$, and glucose stimulated $\mathrm{N}_{2}$ fixation in WS-HC mats in November 2000, but except for glucose, inhibited $\mathrm{N}_{2}$ fixation rates in May 2003. Unamended rates of $\mathrm{N}_{2}$ fixation in WS-HC mats on these dates were significantly different. In NHC-containing mats, nutrient $\left(\mathrm{NH}_{4}{ }^{+}, \mathrm{NO}_{3}{ }^{-}\right.$and organic carbon) amendments had a negative or no effect on $\mathrm{N}_{2}$ fixation rates.
Over longer (days-length) time scales, the response of $\mathrm{N}_{2}$ fixation and denitrification to nutrient enrichment was similar to short-term effects (Tables 4 \& 5). Long-term $\mathrm{NH}_{4}{ }^{+}$enrichment was either inhibitory to $\mathrm{N}_{2}$ fixation at concentrations above $0.1 \mathrm{mM}$ or had no effect. Long-term $\mathrm{NO}_{3}{ }^{-}$enrichment was typically also inhibitory at concentrations above $0.1 \mathrm{mM}$, but stimulatory in one instance (BF-NHC mats in May 2003). Glucose alone stimulated $\mathrm{N}_{2}$ fixation rates, especially at night. Phosphate rarely stimulated $\mathrm{N}_{2}$ fixation $(\mathrm{p}<$ 0.05 in only 1 of 7 bioassays), while acetate, lactate, vitamins and trace metals had no significant effect on $\mathrm{N}_{2}$ fixation. As in short-term experiments, longer-term denitrification rates were controlled by $\mathrm{NO}_{3}{ }^{-}$concentration. $\mathrm{NO}_{3}{ }^{-}$addition increased denitrification rates at concentrations as low as $0.1 \mathrm{mM}$. Additions of $\mathrm{NH}_{4}{ }^{+}$, organic carbon (glucose, acetate, or lactate), phosphate, vitamins, or trace metals had no significant effect on denitrification.

Hydration of desiccated microbial mats from June 2001 generated immediate effects on rates of $\mathrm{N}$ cycling (Fig. 5). HC-containing mats contained greater bulk concentrations of cyanobacteria than NHC-containing mats. Both desiccated $\mathrm{HC}$ and $\mathrm{NHC}$ mats required moist incubations to fix $\mathrm{N}_{2}$, with significantly higher rates under OLW-submerged incubations. Maximum rates of $\mathrm{N}_{2}$ fixation after short-term rehydration (20 min to $4 \mathrm{~h}$ ) were significantly lower than rates in non-desiccated mats. Both desiccated HC and NHC mats showed evidence of denitrification under all hydration regimes (dry, moist, wet, wet/dry, and wet/ moist). Rates of denitrification were enhanced along an increasing moisture gradient with greatest rates after a $20 \mathrm{~min}$ wet pre-incubation. Unlike non-desiccated microbial mats (Figs. 2 to 4 ), rates of denitrification in

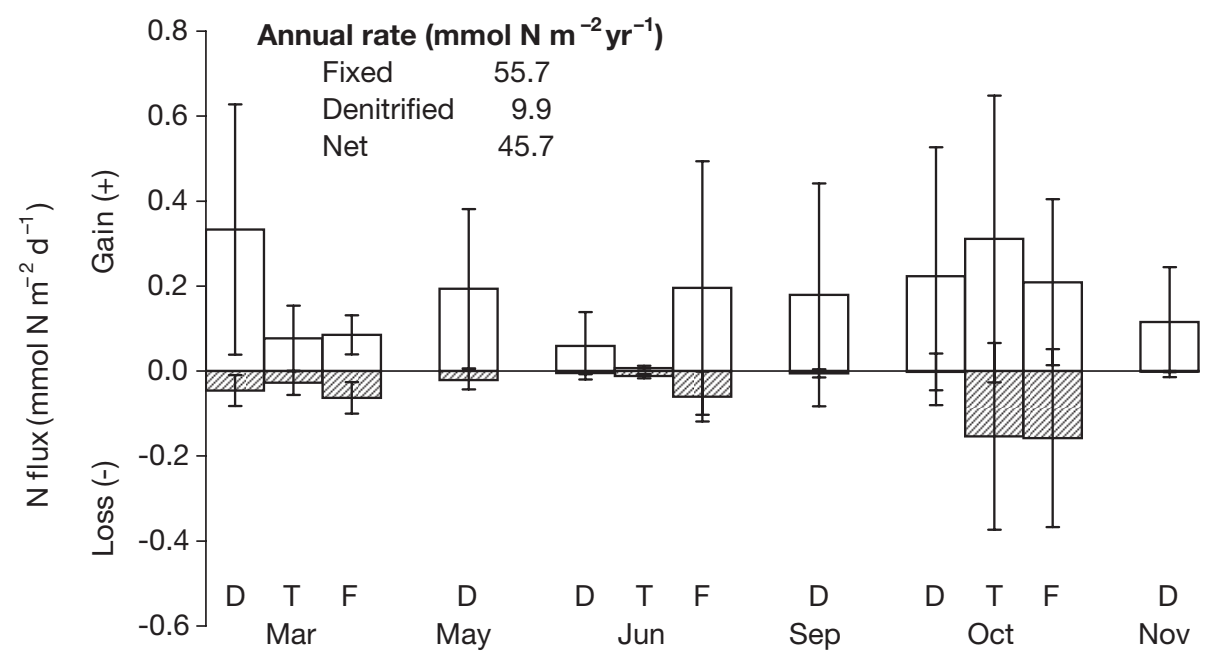

Fig. 4. Seasonal N cycling rates in dwarf (D), transition (T), and fringe (F) habitats. Error bars are standard deviations; annual rates determined by trapezoidal integration 
Table 2. Rates of $\mathrm{N}_{2}$ fixation $\left(\mu \mathrm{mol} \mathrm{N} \mathrm{m}^{-2} \mathrm{~h}^{-1}\right.$ ) in short-term nutrient amendment experiments. ${ }^{*}$ Difference relative to control (2-tailed $t$-test) is significant at $\mathrm{p}<0.1 . \mathrm{Am}: \mathrm{NH}_{4}{ }^{+} ; \mathrm{Ni}$ : $\mathrm{NO}_{3}{ }^{-}$; G: glucose. Subscript: $\mathrm{mM}$ concentration; NHC: nonheterocystous cyanobacterial mats; HC: heterocystous cyanobacterial mats. NWD: North West Dock; WS: Weather Station; BF: Boat Flats; D: Dock

\begin{tabular}{|c|c|c|c|c|c|c|}
\hline & \multicolumn{3}{|c|}{ Nov 00 NWD-NHC } & \multicolumn{3}{|c|}{ Nov 00 WS-HC } \\
\hline & \multicolumn{2}{|c|}{ Light } & $\begin{array}{l}\text { ND-NHC } \\
\text { Dark }\end{array}$ & Light & \multicolumn{2}{|c|}{ Dark } \\
\hline Control & \multicolumn{2}{|r|}{8.1} & 16.5 & 1.4 & \multicolumn{2}{|c|}{0.4} \\
\hline $\mathrm{Am}_{0.5}$ & \multicolumn{2}{|r|}{6.7} & $1.2^{*}$ & $32.8^{*}$ & \multicolumn{2}{|c|}{$6.8^{*}$} \\
\hline $\mathrm{Ni}_{0.5}$ & \multicolumn{2}{|r|}{10.0} & $3.8^{*}$ & 23.0 & \multicolumn{2}{|c|}{$10.3^{*}$} \\
\hline $\mathrm{G}_{1}$ & \multicolumn{2}{|r|}{8.5} & 9.8 & $24.0^{*}$ & \multicolumn{2}{|c|}{$19.6^{*}$} \\
\hline $\mathrm{G}_{1} \mathrm{Ni}_{0.5}$ & \multicolumn{2}{|r|}{7.6} & $3.9^{*}$ & $21.1^{*}$ & \multicolumn{2}{|c|}{$0.7^{*}$} \\
\hline & \multicolumn{3}{|c|}{ May 03 BF-NHC } & \multicolumn{3}{|c|}{ May 03 WS-HC } \\
\hline & \multicolumn{2}{|r|}{ Light } & Dark & Light & \multicolumn{2}{|c|}{ Dark } \\
\hline Control & \multicolumn{2}{|r|}{0.5} & 0.2 & 11.8 & \multicolumn{2}{|c|}{3.8} \\
\hline $\mathrm{Am}_{0.1}$ & \multicolumn{2}{|r|}{$1.0^{*}$} & 0.3 & 9.5 & \multicolumn{2}{|c|}{2.6} \\
\hline $\mathrm{Ni}_{0.1}$ & \multicolumn{2}{|r|}{0.6} & 0.3 & 8.4 & \multicolumn{2}{|c|}{$0.8^{*}$} \\
\hline $\mathrm{Am}_{1}$ & \multicolumn{2}{|r|}{0.7} & 0.3 & 1.1 & \multicolumn{2}{|c|}{$1.2^{*}$} \\
\hline $\mathrm{Ni}_{1}$ & \multicolumn{2}{|r|}{1.1} & 0.2 & 6.2 & \multicolumn{2}{|c|}{$0.6^{*}$} \\
\hline $\mathrm{Am}_{0.1} \mathrm{Ni}_{0.1}$ & \multicolumn{2}{|r|}{0.9} & 0.3 & 5.8 & \multicolumn{2}{|c|}{$0.7^{*}$} \\
\hline $\mathrm{G}_{2} \mathrm{Am}_{0.1} \mathrm{Ni}_{0}$ & \multicolumn{2}{|r|}{1.7} & 0.3 & $6.6^{*}$ & \multicolumn{2}{|c|}{$1.3^{*}$} \\
\hline $\mathrm{G}_{2} \mathrm{Am}_{1} \mathrm{Ni}_{1}$ & & 0.6 & 0.3 & 0.7 & 1.2 & \\
\hline $\mathrm{G}_{0.5}$ & & 0.6 & 0.2 & 7.8 & 10.0 & \\
\hline $\mathrm{G}_{2}$ & & 1.7 & 0.2 & 8.8 & 7.8 & \\
\hline & & & Mar 02 & D-NHC & & \\
\hline & Day & y Night & Day & Night & Day & Night \\
\hline & Dwarf & Irf Dwarf & Transition & ransition & Fringe & Fringe \\
\hline Control & 4.7 & 22.5 & 9.2 & 0.3 & 9.4 & 0.1 \\
\hline $\mathrm{G}_{2} \mathrm{Ni}_{1}$ & $1.8^{*}$ & * $\quad 6.7^{*}$ & $1.2^{*}$ & $0.1^{*}$ & 1.2 & 0.0 \\
\hline AcetateNi & $1.8^{*}$ & * $\quad 4.7^{*}$ & $2.0^{*}$ & $0.0^{*}$ & 1.5 & $0.2^{*}$ \\
\hline LactateNi $_{1}$ & 5.6 & 3.7 & 6.2 & $0.0^{*}$ & 1.7 & 0.0 \\
\hline
\end{tabular}

Table 3. Rates of denitrification $\left(\mu \mathrm{mol} \mathrm{N} \mathrm{m}{ }^{-2} \mathrm{~h}^{-1}\right.$ ) in short-term nutrient amendment experiments. ${ }^{*}$ Difference relative to

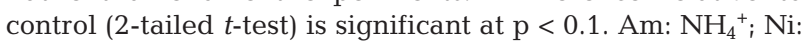
$\mathrm{NO}_{3}{ }^{-}$; G: glucose. Subscript: $\mathrm{mM}$ concentration; NHC: nonheterocystous cyanobacterial mats; HC: heterocystous cyanobacterial mats. NWD: North West Dock; WS: Weather Station; BF: Boa Flats; D: Dock

\begin{tabular}{|c|c|c|c|c|c|}
\hline & \multicolumn{3}{|c|}{ Nov 00 NWD-NHC } & \multicolumn{2}{|c|}{ Nov 00 WS-HC } \\
\hline & Lig & ght & Dark & Light & Dark \\
\hline Control & 0 & 3 & 0.2 & 0.0 & 0.1 \\
\hline $\mathrm{Am}_{0.5}$ & 0 . & 1 & 0.3 & 1.9 & 0.3 \\
\hline $\mathrm{Ni}_{0.5}$ & 14 & $8^{*}$ & $41.0^{*}$ & $8.2^{*}$ & $41.4^{*}$ \\
\hline $\mathrm{G}_{1}$ & & $0^{*}$ & $0.0^{*}$ & 0.0 & $0.0^{*}$ \\
\hline \multirow[t]{3}{*}{$\mathrm{G}_{1} \mathrm{Ni}_{0.5}$} & 12 & $6^{*}$ & $54.0^{*}$ & 17.6 & $76.6^{*}$ \\
\hline & \multicolumn{3}{|c|}{ May 03 BF-NHC } & \multicolumn{2}{|c|}{ May 03 WS-HC } \\
\hline & Lig & ght & Dark & Light & Dark \\
\hline Control & 0 . & 1 & 0.0 & 0.0 & 0.0 \\
\hline $\mathrm{Am}_{0.1}$ & 0 . & 0 & 0.0 & 0.0 & 0.0 \\
\hline $\mathrm{Ni}_{0.1}$ & & $0^{*}$ & 0.6 & 0.3 & $45.4^{*}$ \\
\hline $\mathrm{Am}_{1}$ & & $0^{*}$ & 0.0 & 0.1 & 0.0 \\
\hline $\mathrm{Ni}_{1}$ & 23 & & 1.4 & 2.7 & $103.6^{*}$ \\
\hline $\mathrm{Am}_{0.1} \mathrm{Ni}_{0.1}$ & & $0^{*}$ & $0.2^{*}$ & 4.2 & $70.8^{*}$ \\
\hline $\mathrm{G}_{2} \mathrm{Am}_{0.1} \mathrm{Ni}_{0}$ & & $4^{*}$ & $0.2^{*}$ & $3.0^{*}$ & $75.0^{*}$ \\
\hline $\mathrm{G}_{2} \mathrm{Am}_{1} \mathrm{Ni}_{1}$ & 11. & & 0.0 & 5.4 & $113.8^{*}$ \\
\hline $\mathrm{G}_{0.5}$ & & $0^{*}$ & 0.0 & 0.0 & 0.5 \\
\hline \multirow[t]{4}{*}{$\mathrm{G}_{2}$} & 0 . & 0 & 0.0 & $0.0^{*}$ & $0.0^{*}$ \\
\hline & \multicolumn{5}{|c|}{ Mar 02 D-NHC } \\
\hline & Day & Night & Day & Night & Day Night \\
\hline & \multicolumn{5}{|c|}{ Dwarf Dwarf Transition Transition Fringe Fringe } \\
\hline Control & 0.4 & 0.0 & 0.7 & 0.1 & $2.0 \quad 1.1$ \\
\hline $\mathrm{G}_{2} \mathrm{Ni}_{1}$ & 21.4 & $78.2^{*}$ & $130.6^{*}$ & $271.4^{*}$ & $103.0^{*} 172.8^{*}$ \\
\hline AcetateNi $\mathrm{Ni}_{1}$ & 12.9 & $72.6^{*}$ & $107.8^{*}$ & $223.0^{*}$ & $100.5170 .8^{*}$ \\
\hline LactateNi $_{1}$ & $22.2^{*}$ & $92.2^{*}$ & $145.4^{*}$ & $142.4^{*}$ & $159.4^{*} 273.4^{*}$ \\
\hline
\end{tabular}

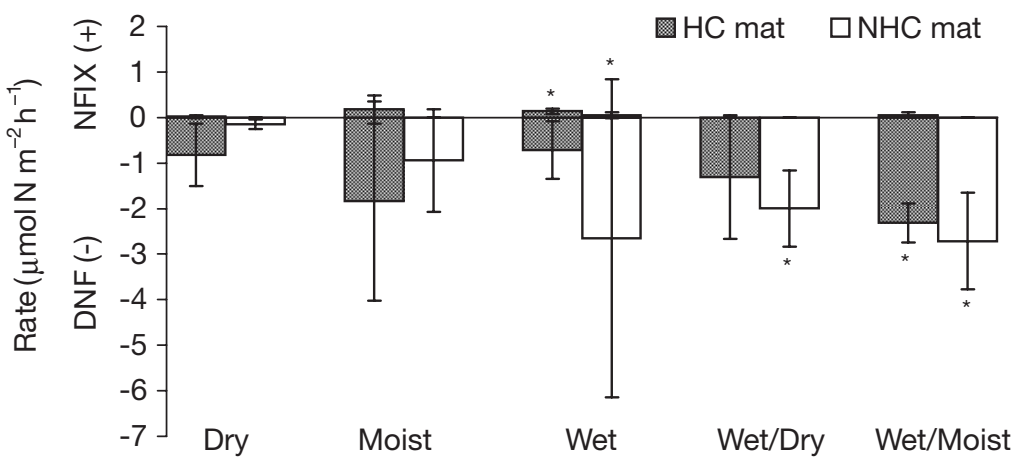

Fig. 5. Hourly hydration effects on $\mathrm{N}_{2}$ fixation (NFIX) and denitrification (DNF) rates ( $\mu$ mol $\mathrm{N} \mathrm{m}^{-2} \mathrm{~h}^{-1}$ ) in a desiccated heterocystous cyanobacterial (HC) dwarf mat and a dessicated non-heterocystous cyanobacterial (NHC) dwarf mat. Daytime incubations included dry: control, i.e. no overlying water (OLW); moist: 3 drops OLW; wet: $10 \mathrm{ml}$ OLW; wet/dry: dry incubation following a 20 min submersion in OLW; wet/moist: 3 drops OLW incubation following a $20 \mathrm{~min}$ submersion in OLW. Error bars are standard deviations. ${ }^{*}$ Difference relative to control (2-tailed $t$-test) is $\mathrm{p}<0.1$ dehydrated mats exceeded $\mathrm{N}_{2}$ fixation rates under all degrees of rehydration.

Under longer-term rehydration regimes, $\mathrm{N}_{2}$ fixation again dominated $\mathrm{N}$ cycling activity compared to denitrification (Fig. 6). Non-desiccated (wet) NHC microbial mats exhibited higher $\mathrm{N}_{2}$ fixation rates than both desiccated (dry) NHC and desiccated (dry) HC mats. Negligible rates of $\mathrm{N}_{2}$ fixation occurred in dry incubations compared to wet incubations in both wet and dry NHC mats. One day of wet mat dehydration decreased rates of $\mathrm{N}_{2}$ fixation to the same degree as daily-alternating and 2 and $5 \mathrm{~d}$ of dehydration. After $\geq 1 \mathrm{~d}$ of dehydration and subsequent wet incubation, NHC mat $\mathrm{N}_{2}$ fixation rates consistently equaled dry NHC mat fixation after $>1 \mathrm{~d}$ of rehydration and wet incubation. No 
Table 4. Rates of $\mathrm{N}_{2}$ fixation ( $\mu \mathrm{mol} \mathrm{N} \mathrm{m}{ }^{-2} \mathrm{~h}^{-1}$ ) in nutrient bioassay experiments. ${ }^{*}$ Difference relative to control (2-tailed $t$-test) is significant at $\mathrm{p}<0.1$. Am: $\mathrm{NH}_{4}{ }^{+} ; \mathrm{Ni}: \mathrm{NO}_{3}{ }^{-} ; \mathrm{P}: \mathrm{PO}_{4}{ }^{3-}$; G: glucose; see text for other treatment details. Subscript: mM concentration; HC: heterocystous cyanobacterial mat; NHC: non-heterocystous cyanobacterial mat. WS: Weather Station; BF: Boa Flats; NWD: North West Dock

\begin{tabular}{|c|c|c|c|c|c|c|c|c|c|c|c|c|c|c|c|}
\hline & \multicolumn{2}{|c|}{$\begin{array}{l}\text { Nov } 00 \\
\text { WS-HC } \\
\text { Light Dark }\end{array}$} & \multicolumn{2}{|c|}{$\begin{array}{l}\text { Nov } 00 \\
\text { BF-NHC }\end{array}$} & \multicolumn{2}{|c|}{$\begin{array}{c}\text { Nov } 00 \\
\text { NWD-NHC }\end{array}$} & \multicolumn{2}{|c|}{$\begin{array}{c}\text { Jun } 01 \\
\text { WS-NHC }\end{array}$} & \multicolumn{2}{|c|}{$\begin{array}{c}\text { Mar 02 } \\
\text { WS-NHC }\end{array}$} & & \multicolumn{2}{|c|}{$\begin{array}{l}\text { May } 03 \\
\text { BF-NHC }\end{array}$} & \multicolumn{2}{|c|}{$\begin{array}{l}\text { May } 03 \\
\text { WS-HC }\end{array}$} \\
\hline Control & 0.2 & 1.3 & 9.0 & 22.9 & 5.6 & 16.0 & 3.7 & 4.2 & 46.6 & 15.1 & Control & 1.0 & 1.6 & 2.6 & 0.5 \\
\hline $\mathrm{Am}_{0.05} \mathrm{Ni}_{0.1}$ & 0.2 & 0.5 & 7.1 & 3.8 & 3.8 & $0.1^{*}$ & 3.4 & 2.3 & 39.5 & 17.0 & $\mathrm{Am}_{0.1}$ & 4.0 & 3.1 & 1.9 & 0.4 \\
\hline $\mathrm{P}$ & $1.4^{*}$ & 2.1 & 11.8 & 23.8 & 8.4 & 18.5 & 3.7 & 4.7 & 48.1 & 11.8 & $\mathrm{Ni}_{0.1}$ & $2.3^{*}$ & 1.5 & 1.7 & 0.4 \\
\hline $\mathrm{PAm}_{0.05} \mathrm{Ni}_{0.1}$ & $0.5^{*}$ & 0.8 & 8.5 & 5.4 & $2.3^{*}$ & $0.2^{*}$ & 2.7 & 4.7 & 54.7 & 7.6 & $\mathrm{Am}_{0.5}$ & 1.9 & 1.5 & $0.8^{*}$ & 0.3 \\
\hline $\mathrm{G}_{1}$ & 2.4 & $18.5^{*}$ & 23.0 & $112.1^{*}$ & 11.3 & $38.5^{*}$ & 4.0 & 10.9 & 58.0 & 25.9 & $\mathrm{Ni}_{0.5}$ & 1.3 & 1.3 & $0.7^{*}$ & 0.3 \\
\hline $\mathrm{G}_{1} \mathrm{Ni}_{0.5}$ & 0.3 & 1.2 & $4.3^{*}$ & 3.2 & 4.5 & $0.8^{*}$ & $1.2^{*}$ & $0.9^{*}$ & 43.4 & $1.7^{*}$ & $\mathrm{Am}_{1}$ & 18.5 & 1.4 & $0.4^{*}$ & $0.1^{*}$ \\
\hline Acetate & - & - & - & - & - & - & - & - & 57.9 & 13.9 & $\mathrm{Ni}_{1}$ & $1.9^{*}$ & 1.5 & $0.5^{*}$ & $0.1^{*}$ \\
\hline Lactate & - & - & - & - & - & - & - & - & 52.7 & 22.7 & $\mathrm{P}$ & 22.6 & 1.9 & $1.0^{*}$ & 0.3 \\
\hline Iron & 0.3 & 4.7 & 7.6 & 18.5 & 9.2 & 13.2 & 2.5 & 3.8 & 69.8 & 14.7 & $\mathrm{PAm}_{0.1} \mathrm{Ni}_{0.1}$ & 7.9 & 1.8 & $1.4^{*}$ & 0.3 \\
\hline Trace metals & - & - & - & - & - & - & - & - & 64.8 & 6.5 & $\mathrm{G}_{0.5}$ & 14.9 & 2.5 & $0.5^{*}$ & 0.2 \\
\hline Vitamins & - & - & - & - & - & - & - & - & 64.7 & 15.6 & $\mathrm{G}_{2}$ & 9.0 & 1.4 & 3.3 & 1.3 \\
\hline & & & & & & & & & & & $\mathrm{G}_{2} \mathrm{Am}_{0.1} \mathrm{Ni}_{0.1}$ & 8.2 & 5.8 & $0.5^{*}$ & 1.0 \\
\hline
\end{tabular}

Table 5. Rates of denitrification $\left(\mu \mathrm{mol} \mathrm{N} \mathrm{m} \mathrm{N}^{-2} \mathrm{~h}^{-1}\right.$ in nutrient bioassay experiments. See Table 4 for details

\begin{tabular}{|c|c|c|c|c|c|c|c|c|c|c|c|c|c|c|c|}
\hline \multirow[b]{2}{*}{ Control } & \multicolumn{2}{|c|}{$\begin{array}{c}\text { Nov } 00 \\
\text { WS-HC } \\
\text { Light Dark }\end{array}$} & \multicolumn{2}{|c|}{$\begin{array}{c}\text { Nov } 00 \\
\text { BF-NHC } \\
\text { Light Dark }\end{array}$} & \multicolumn{2}{|c|}{$\begin{array}{c}\text { Nov } 00 \\
\text { NWD-NHC } \\
\text { Light Dark }\end{array}$} & \multicolumn{2}{|c|}{$\begin{array}{c}\text { Jun } 01 \\
\text { WS-NHC } \\
\text { Light Dark }\end{array}$} & \multicolumn{2}{|c|}{$\begin{array}{c}\text { Mar } 02 \\
\text { WS-NHC } \\
\text { Light Dark }\end{array}$} & \multirow[b]{2}{*}{ Control } & \multicolumn{2}{|c|}{$\begin{array}{c}\text { May } 03 \\
\text { BF-NHC } \\
\text { Light Dark }\end{array}$} & \multicolumn{2}{|c|}{$\begin{array}{c}\text { May } 03 \\
\text { WS-HC }\end{array}$} \\
\hline & 0.0 & 0.0 & 0.0 & 0.0 & 0.0 & 0.0 & 0.0 & 0.0 & 1.4 & 1.2 & & 0.1 & 0.0 & 0.4 & 0.0 \\
\hline $\mathrm{Am}_{0.05} \mathrm{Ni}_{0.1}$ & $0.4^{*}$ & $2.6^{*}$ & $3.6^{*}$ & $9.6^{*}$ & $19.6^{*}$ & $106.0^{*}$ & 0.1 & 0.4 & $0.2^{*}$ & 1.0 & $\mathrm{Am}_{0.1}$ & 0.1 & 0.0 & 0.5 & 0.0 \\
\hline $\mathrm{P}$ & $0.0^{*}$ & 0.0 & 0.2 & 0.0 & 0.1 & 1.3 & 0.0 & $0.0^{*}$ & $0.2^{*}$ & 1.2 & $\mathrm{Ni}_{0.1}$ & $0.0^{*}$ & 0.0 & 0.1 & $0.0^{*}$ \\
\hline $\mathrm{PAm}_{0.05} \mathrm{Ni}_{0.1}$ & 0.1 & 3.3 & 4.5 & 6.2 & 16.6 & 83.1 & 0.2 & 0.1 & 1.3 & 2.7 & $\mathrm{Am}_{0.5}$ & $0.0^{*}$ & 0.0 & 0.0 & 0.0 \\
\hline $\mathrm{G}_{1}$ & 0.0 & 0.0 & 0.1 & 0.0 & 0.0 & 0.2 & 0.0 & 0.2 & 2.3 & 1.2 & $\mathrm{Ni}_{0.5}$ & $0.0^{*}$ & 0.0 & 0.0 & $0.0^{*}$ \\
\hline $\mathrm{G}_{1} \mathrm{Ni}_{0.5}$ & $1.4^{*}$ & 2.6 & 5.3 & $91.2^{*}$ & $23.2^{*}$ & $93.2^{*}$ & $8.0^{*}$ & 37.5 & 3.0 & $4.4^{*}$ & $\mathrm{Am}_{1}$ & 0.5 & 0.0 & 0.0 & 0.3 \\
\hline Acetate & - & - & - & - & - & - & - & - & 1.3 & 1.2 & $\mathrm{Ni}_{1}$ & 4.2 & 0.0 & 5.8 & 34.1 \\
\hline Lactate & - & - & - & - & - & - & - & - & 1.8 & 0.6 & $\mathrm{P}$ & 0.0 & 0.0 & 0.0 & 0.2 \\
\hline Iron & 0.0 & 0.1 & 0.0 & 0.0 & 0.1 & 0.9 & 0.0 & 0.1 & 1.7 & 0.9 & $\mathrm{PAm}_{0.1} \mathrm{Ni}_{0.1}$ & 0.0 & 0.0 & 0.0 & $0.0^{*}$ \\
\hline Trace metals & - & - & - & - & - & - & - & - & 1.1 & 0.9 & $\mathrm{G}_{0.5}$ & 0.0 & 0.0 & 0.0 & $0.0^{*}$ \\
\hline Vitamins & - & - & - & - & - & - & - & - & 2.2 & 0.9 & $\mathrm{G}_{2}$ & 0.0 & 0.1 & 4.2 & $2.2^{*}$ \\
\hline & & & & & & & & & & & $\mathrm{G}_{2} \mathrm{Am}_{0.1} \mathrm{Ni}_{0.1}$ & 0.0 & 0.0 & 2.6 & $2.0^{*}$ \\
\hline
\end{tabular}

difference in $\mathrm{N}_{2}$ fixation was evident between any treatment of wet NHC and dry NHC mats incubated under air or helium.

$\mathrm{N}_{2}$ fixation in desiccated $\mathrm{HC}$ mats increased after $1 \mathrm{~d}$ of rehydration to maximum rates after $2 \mathrm{~d}$ of rehydration. $\mathrm{N}_{2}$ fixation after $5 \mathrm{~d}$ of rehydration was the same as after $1 \mathrm{~d}$. Unlike wet and dry NHC mats, $\mathrm{N}_{2}$ fixation in desiccated HC mats occurred under both wet and dry incubations following rehydration. $\mathrm{N}_{2}$ fixation in dry HC mats was insignificantly enhanced by incubation under helium.

Denitrification rates were also affected by rehydration regimes. Both non-desiccated and desiccated NHC mats exhibited minimal rates of denitrification, and hydration had no impact on denitrification activity. Desiccated HC mats exhibited denitrification under dry conditions, and activity in dry incubations often exceeded activity in wet incubations. As rehydration durations increased from 1 to 2 to $5 \mathrm{~d}$, rates of denitrification in desiccated HC mats decreased from maximal rates after $1 \mathrm{~d}$ of rehydration to minimal rates after $5 \mathrm{~d}$ of rehydration. In all mat types studied, denitrification rates in incubations under air were the same as in under helium-purged conditions.

\section{DISCUSSION}

\section{Physiological controls}

Diel patterns of $\mathrm{N}_{2}$ fixation in Twin Cays fringe, transition and dwarf microbial mats were controlled primarily by strategies to decrease $\mathrm{O}_{2}$ inhibition of the nitrogenase enzyme. Mats dominated by HC demon- 
a. Non-desiccated NHC mat

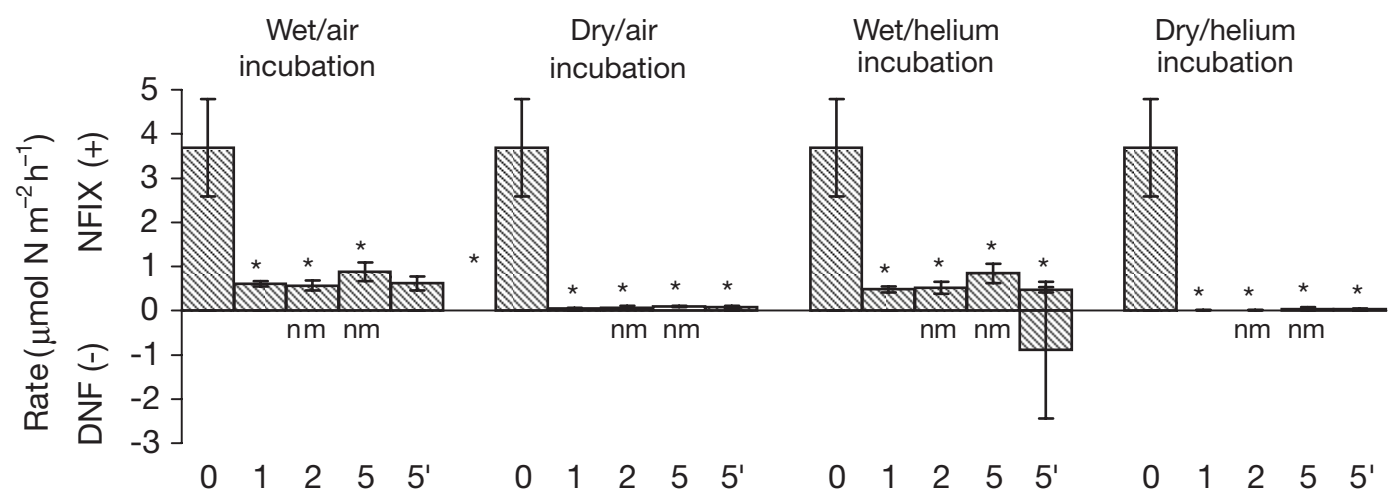

b. Desiccated NHC mat

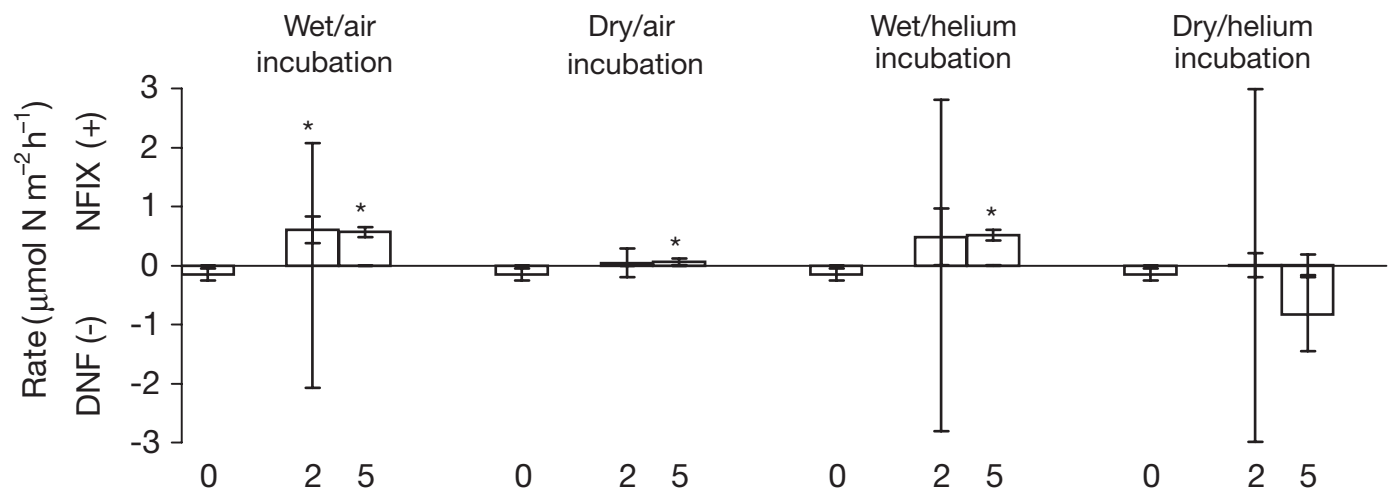

c. Desiccated HC mat

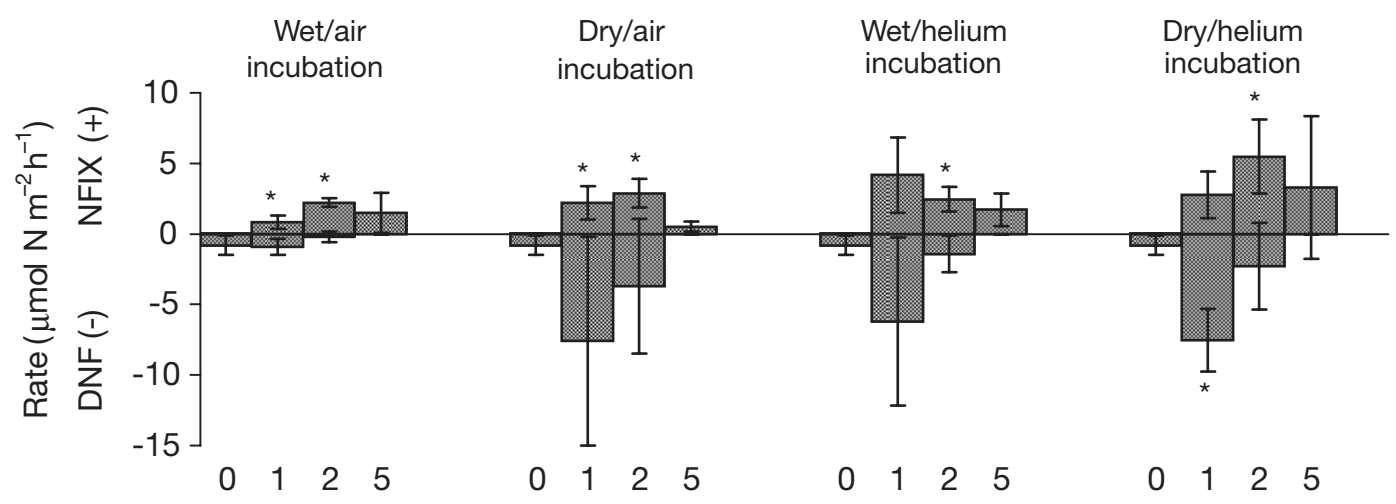

Fig. 6. Longer-term (1 to $5 \mathrm{~d}$ ) rehydration and/or desiccation effects on $\mathrm{N}_{2}$ fixation (NFIX) and denitrification (DNF) rates ( $\mu$ mol $\mathrm{N}$ $\mathrm{m}^{-2} \mathrm{~h}^{-1}$ ) in (a) a non-desiccated non-heterocystous cyanobacterial (NHC) dwarf mat, (b) a desiccated NHC dwarf mat, and (c) a desiccated heterocystous cyanobacterial (HC) mat. Daytime incubations occurred with (wet) or without (dry) $10 \mathrm{ml}$ overlying water and under air or helium. 0: control, i.e. dry incubation of desiccated mat or wet incubation of non-desiccated mat; 1: $1 \mathrm{~d}$ opposite; 2: 2 d opposite; 5: 5 d opposite; 5': 5 d alternate. Opposite: hydration of desiccated mat or desiccation of non-desiccated mat; alternate: alternating days of hydration and desiccation. Error bars are standard deviations. * Difference relative to control (2-tailed $t$-test) is significant at $\mathrm{p}<0.1 ; \mathrm{nm}$ : not measured

strated their ability to photosynthesize and fix $\mathrm{N}_{2}$ contemporaneously by greater daytime $\mathrm{N}_{2}$ fixation rates, while NHC-containing mats fixed $\mathrm{N}_{2}$ at low rates under daytime $\mathrm{O}_{2}$-rich conditions and exhibited maxi- mal rates during low $\mathrm{O}_{2}$ conditions at night. $\mathrm{HC}$ can fix $\mathrm{N}_{2}$ during the day in specialized heterocysts lacking $\mathrm{O}_{2}$-generating PS-II and surrounded by thick cell walls of glycolipid and polysaccharide that serve as a barrier 
to $\mathrm{O}_{2}$ diffusion into the cell. Temporal separation of daytime photosynthetic $\mathrm{O}_{2}$ production from nighttime $\mathrm{N}_{2}$ fixation occurs in unicellular and filamentous cyanobacteria lacking heterocysts (Stal 1995). Other organisms are able to support $\mathrm{N}_{2}$ fixation by exploiting deeper anoxic layers or existing within surficial anaerobic microzones of the microbial mat (e.g. sulfate reducing bacteria), while phototrophic sulfur bacteria possess only PS-I, which does not produce $\mathrm{O}_{2}$ (Paerl \& Pinckney 1996).

The sizeable stimulation of $\mathrm{N}_{2}$ fixation by DCMU did not simply reflect the release of inhibition of $\mathrm{O}_{2}$-sensitive $\mathrm{N}_{2}$ fixers, but underscored the importance of PS-I in supplying energy and reductant in support of $\mathrm{N}_{2}$ fixation. Cyanobacteria and phototrophic sulfur bacteria may use $\mathrm{H}_{2} \mathrm{~S}$ as a source of electrons for $\mathrm{CO}_{2}$ fixation, and cyanobacteria may funnel electrons from $\mathrm{H}_{2} \mathrm{~S}$ or NADH/NADPH oxidation (generated from the catabolism of fixed carbon) through PS-I to fix $\mathrm{N}_{2}$ (Bebout et al. 1993). Phototrophic release of fixed-carbon (e.g. DOC) may stimulate heterotrophic $\mathrm{N}_{2}$ fixation (Paerl et al. 1987, Paerl 1990). Rates of $\mathrm{N}_{2}$ fixation in dark incubations over a diel cycle were relatively constant, showing that a fraction of the community fixing $\mathrm{N}_{2}$ was independent of light-driven stimulation. In contrast to diel patterns of $\mathrm{N}_{2}$ fixation, denitrification rates were influenced by $\mathrm{O}_{2}$ only when ample $\mathrm{NO}_{3}{ }^{-}$was available. The controls on denitrification in Twin Cays' habitats are discussed further in subsequent sections.

\section{Physical environmental controls}

$\mathrm{N}_{2}$ fixation and denitrification by Twin Cays' mangrove microbial mats were affected by a variety of factors including the physical environment, redox conditions, and community composition. Shaded and tidally-flushed or air-exposed fringe and transition soils were colonized by oxygenic phototrophs including primarily diatoms and eukaryotic algae, and a fraction of unicellular and non-heterocystous filamentous cyanobacteria. In contrast, dwarf habitat mats were dominated by cyanobacteria, including unicellular and non-heterocystous and heterocystous filamentous forms, purple sulfur bacteria, and other microbes more tolerant of heat, salt, sulfide, irradiation, and desiccation stresses.

$\mathrm{N}_{2}$ fixing communities proliferated in all habitats during wet seasons, but during dry spring and early summer seasons, $\mathrm{N}_{2}$ fixation was influenced strongly by inundation patterns. Under dry season low tides in March and June, transition habitat $\mathrm{N}_{2}$ fixation rates were lowest because the combination of low tides and high elevation resulted in the greatest exposure of these mats. The extreme low tides, decreased rainfall and increased temperatures in June, decreased rates of dwarf mat $\mathrm{N}_{2}$ fixation, while fringe mats maintained average rates of $\mathrm{N}_{2}$ fixation due to continual flushing by dry season high tides.

During the dry season, extreme low tides exposed the mats for days at a time to direct solar irradiation and desiccation. Under desiccated conditions, rates of $\mathrm{N}_{2}$ fixation were immeasurable in NHC-containing mats, and low, but measurable in HC-containing mats, which were encased in yellow-brown colored sheaths, indicative of the UV-absorbing pigment scytonemin. Wetting of dried mat restored cellular water content, which may have altered local $\mathrm{O}_{2}$ concentrations by restoring metabolisms that generate anoxic conditions at depth, as well as restoring oxygenic photosynthesis at the surface. Metabolic functions in rehydrated Nostoc began with respiration, followed by photosynthesis, and finally $\mathrm{N}_{2}$ fixation (Potts 1999). Denitrification was more resilient to dehydration than $\mathrm{N}_{2}$ fixation. We suspect this resilience resulted from physiological factors because denitrification was often inhibited by photosynthetic $\mathrm{O}_{2}$ production, suggesting that denitrification and $\mathrm{N}_{2}$ fixation occurred in similar depth horizons, yet distinct redox microzones.

In non-desiccated and dehydrated NHC-containing mats, exposure to atmospheric $\mathrm{O}_{2}$ was not inhibitory under wet conditions, possibly because $\mathrm{O}_{2}$ diffusion through water is slower than in air and respiration maintained $\mathrm{O}_{2}$ concentrations at a level non-inhibitory to $\mathrm{N}_{2}$ fixers. Denitrification in NHC-containing mats was insignificant. In desiccated HC-containing mats, recovery of $\mathrm{N}_{2}$ fixing activity was rapid after rehydration. HC-containing mats are thus presumably more resilient to changes in hydration, which may explain their greater abundance in the high intertidal relative to NHC-containing mats (Potts 1980). Alternating changes in water content in the high intertidal may also contribute to nitrification-linked denitrification, which may explain the occurrence of higher denitrification rates in HC-containing mats.

\section{Chemical environmental controls}

Twin Cays' microbial mat redox conditions were controlled by seasonal changes in hydrology, autochthonous production of $\mathrm{O}_{2}$ by phototrophs, $\mathrm{O}_{2}$ consumption by biotic and abiotic processes, and anaerobic metabolism. Photosynthetic $\mathrm{O}_{2}$ production had a substantial diel effect on the environment of $\mathrm{N}_{2}$ fixing and denitrifying bacteria by directly altering local $\mathrm{O}_{2}$ concentration and the redox states of metabolic reactants. Elevated concentrations of reduced chemical species, such as $\mathrm{H}_{2} \mathrm{~S}$ and $\mathrm{NH}_{4}{ }^{+}$, accumulated at depth, especially in the almost continually-submerged dwarf 
habitat mats, and diffused towards the microbial mats to be metabolized by a diverse array of mat microbes, e.g. chemoautotrophs, heterotrophs, or photoautotrophs, or to pass through the microbial mats and flux into the overlying water.

$\mathrm{N}_{2}$ fixation incurs a large metabolic cost (16 ATP per $\mathrm{N}_{2}$ reduced), and environmental $\mathrm{NH}_{4}{ }^{+}$availability can repress nitrogenase synthesis (Postgate 1982). $\mathrm{N}_{2}$ fixation in Twin Cays' dwarf mats was inhibited when $\mathrm{NH}_{4}{ }^{+}$concentrations exceeded $0.5 \mathrm{mM}$ (data not shown). This value falls within the inhibitory range of 50 to $500 \mu \mathrm{M}$ observed in other studies (Capone 1988, Valiente et al. 1997). Transition and fringe fixation rates varied independently of porewater $\mathrm{NH}_{4}{ }^{+}$concentrations which were consistently less than $20 \mu \mathrm{M}$, and thus not likely the primary factor controlling $\mathrm{N}_{2}$ fixation in those habitats.

Negative effects of $\mathrm{H}_{2} \mathrm{~S}$ on $\mathrm{N}_{2}$ fixation have been attributed to $\mathrm{pH}$-dependent direct sulfide toxicity (Tam et al. 1982). But microbial mat $\mathrm{N}_{2}$ fixers, including sulfur-oxidizing bacteria and cyanobacteria, can oxidize $\mathrm{H}_{2} \mathrm{~S}$ (Bebout et al. 1993). Cyanobacteria also demonstrate a differential tolerance to $\mathrm{H}_{2} \mathrm{~S}$ addition based on morphology. HC-dominated mats along the Mediterranean coast exhibited decreased $\mathrm{N}_{2}$ fixation under 1 to $10 \mathrm{mM} \mathrm{H}_{2} \mathrm{~S}$ addition, while NHC-mats were stimulated by the same $\mathrm{H}_{2} \mathrm{~S}$ amendments (Villbrandt \& Stal 1996). Most dwarf mats observed on Twin Cays were dominated by NHC and purple sulfur bacteria, and thus may have been capable of sustaining $\mathrm{N}_{2}$ fixation rates across the broad ranges of in situ $\mathrm{H}_{2} \mathrm{~S}$ concentrations.

Substrate limitation of denitrification by $\mathrm{NO}_{3}^{-}$and glucose was evident in all habitats, and transition and fringe mats exhibited greater rates of denitrification than dwarf mats. Caribbean coral reef and mangrove prop root sponges have been found to release large amounts of $\mathrm{NO}_{3}{ }^{-}$to the surrounding environment (Diaz $\&$ Ward 1997). Fringe and transition mats may experience significant and erratic inputs of $\mathrm{NO}_{3}^{-}$from sponges on reefs and fringe prop roots, so that when $\mathrm{NO}_{3}{ }^{-}$is available, the existing denitrifying population is capable of rapid consumption.

Denitrifiers in fringe and transition habitats also had the advantage of living in less sulfidic conditions compared to dwarf habitats. Sulfide is inhibitory to denitrification (Sorensen et al. 1980) and also nitrification (Joye \& Hollibaugh 1995), which may be coupled to denitrification in these fluctuating aerobicanaerobic, $\mathrm{NH}_{4}{ }^{+}$-rich environments. Unfortunately, acetylene inhibits nitrification, while sulfide interferes with the acetylene block measurement of denitrification. Quantification of coupled nitrificationdenitrification in these habitats is a topic for future study.

\section{Short-term (hourly) and long-term (days-long) nutrient controls}

$\mathrm{NO}_{3}{ }^{-}$was the primary control on denitrification in both short- and long-term nutrient incubations, while $\mathrm{NH}_{4}{ }^{+}, \mathrm{DOC}, \mathrm{P}$, vitamins, and trace metals had no effect. Denitrification was primarily $\mathrm{NO}_{3}{ }^{-}$limited, but when $\mathrm{NO}_{3}{ }^{-}$was available, nighttime potential denitrification rates exceeded daytime rates, suggesting that denitrifiers were inhibited by $\mathrm{O}_{2}$ during the day. The large variability in diel activity may have been due to the heterogeneity of denitrifier populations or the presence of anaerobic microzones (Paerl \& Pinckney 1996).

Labile DOC (e.g. glucose) has been observed to stimulate aerobic respiration, and by decreasing $\mathrm{O}_{2}$ concentrations, stimulate $\mathrm{N}_{2}$ fixation in NHC-containing mats more than in HC-containing mats (Paerl et al. 1987, Villbrandt \& Stal 1996). In this system, DOC stimulation of $\mathrm{N}_{2}$ fixation occurred only in $\mathrm{HC}$-containing mats. DOC stimulation of $\mathrm{O}_{2}$ respiration may have enhanced photosynthetic sulfur bacterial $\mathrm{H}_{2} \mathrm{~S}$ oxidation, thus decreasing local $\mathrm{H}_{2} \mathrm{~S}$ concentrations and relieving $\mathrm{H}_{2} \mathrm{~S}$-inhibition of $\mathrm{HC} \mathrm{N}_{2}$ fixation. Since $\mathrm{HC}$ are more sensitive to sulfide (as noted above), DOC stimulation of $\mathrm{H}_{2} \mathrm{~S}$ oxidation would influence activity in $\mathrm{HC}$-containing mats more than in NHC-containing mats. Longer-term DOC addition significantly increased $\mathrm{N}_{2}$ fixation in some dark treatments attesting that stimulation of $\mathrm{N}_{2}$ fixation by DOC is not due to increased oxygen consumption alone, but also that DOC was used as a carbon and energy source for heterotrophic $\mathrm{N}_{2}$ fixation (Paerl et al. 1993).

Environmental availability of fixed $\mathrm{N}$ (e.g. $\mathrm{NH}_{4}{ }^{+}$and $\mathrm{NO}_{3}{ }^{-}$) can inhibit $\mathrm{N}_{2}$ fixation by suppressing nitrogenase synthesis and 'switching-off' nitrogenase activity, but the majority of mats demonstrated no significant change in $\mathrm{N}_{2}$ fixation with $\mathrm{NH}_{4}{ }^{+}$or $\mathrm{NO}_{3}{ }^{-}$addition irrespective of habitat or season. Paerl et al. (1989) also noted the absence of DIN inhibition of $\mathrm{N}_{2}$ fixation with additions of up to $\sim 55 \mu \mathrm{M} \mathrm{NH}_{4}{ }^{+}$in Shackleford Banks (NC, USA) microbial mats, while DIN inhibition of $\mathrm{N}_{2}$ fixation has been documented at a variety of concentrations in aquatic environments (e.g. 4 to $>70 \mu \mathrm{M} \mathrm{DIN}$; Horne \& Commins 1987, MacKay \& Elser 1998). High porewater $\mathrm{NH}_{4}{ }^{+}$concentrations in both Twin Cays dwarf habitats $\left(257.4 \mu \mathrm{M} \mathrm{NH}_{4}{ }^{+}\right.$at $10 \mathrm{~cm}$ depth) and Shackleford Banks ( 8.8 $\left.\mathrm{MM} \mathrm{NH}_{3}\right)$ may have repressed nitrogenase activity prior to experimental $\mathrm{N}$ amendment. We suspect that in dwarf mats stimulated by DIN additions, heterotrophic $\mathrm{O}_{2}$ respiration was stimulated, which decreased $\mathrm{O}_{2}$ inhibition of $\mathrm{N}_{2}$ fixation.

Phosphorus, vitamins and trace metals did not limit activity of $\mathrm{N}_{2}$ fixers. Similar results have been found in other environments, including Bahamian stromatolites and mats from Mexican lagoons, North Carolinian 
coastal islands, and California coastal marshes (Paerl et al. 1987, 1993). In contrast, some environments, including North Carolinian mats (Pinckney et al. 1995), have exhibited phosphate limitation of $\mathrm{N}_{2}$ fixation. Clearly, nutrient controls on $\mathrm{N}_{2}$ fixation limitation vary locally, and each site needs to be examined as an independent system.

\section{Ecosystem-level importance of microbial mats}

The adaptation of Twin Cays microbial mat communities to redox and nutrient conditions in each habitat influences their role as either a source or sink of $\mathrm{N}$ in the system. Fringe and transition mats demonstrated a significantly greater denitrification capacity than dwarf mats, while $\mathrm{N}_{2}$ fixation dominated dwarf habitats. Integrated unamended denitrification rates across all sites $\left(9.9 \mathrm{mmol} \mathrm{N} \mathrm{m} \mathrm{N}^{-2} \mathrm{yr}^{-1}\right)$ were much lower than those of $\mathrm{N}_{2}$ fixation (55.7 $\mathrm{mmol} \mathrm{N} \mathrm{m}^{-2} \mathrm{yr}^{-1}$ ), clearly showing that benthic processes serve as an important net source of $\mathrm{N}$ to the oligotrophic Twin Cays mangrove ecosystem (Joye \& Lee 2004).

Variability in benthic N dynamics helps explain nutrient limitation patterns of mangrove trees in each habitat. Twin Cays fringe mangrove trees are N-limited, while dwarf trees are P-limited, and transition trees are co-limited by $\mathrm{N}$ and $\mathrm{P}$ (Feller et al. 2003). Microbial mats serve as a significant $\mathrm{N}$ source to dwarf mangrove trees via $\mathrm{N}_{2}$ fixation, thereby alleviating $\mathrm{N}$-limitation and contributing to the observed P-limitation of trees in this zone. Fringe and transition mats have the potential to serve as sources of $\mathrm{N}$ to their respective habitats, but elevated rates of denitrification in fringe and transition microbial mats may limit DIN availability to fringe and transition mangrove trees by competing for available $\mathrm{NO}_{3}{ }^{-}$. Coupled nitrification-denitrification could further exacerbate $\mathrm{N}$ limitation in mats and trees from these habitats.

The rates of $\mathrm{N}_{2}$ fixation and denitrification observed in Twin Cays microbial mats were comparable to rates of N cycling observed in other mangrove cyanobacterial mats and soils (Table 6). Denitrification rates in all

Table 6. Summary of mangrove $\mathrm{N}_{2}$ fixation (NFIX) and denitrification (DNF) rates $\left(\mathrm{mmol} \mathrm{N}^{-2} \mathrm{~d}^{-1}\right.$ ). R: Rhizophora; A: Avicennia; L: Laguncularia; C: Ceriops; B: Bruguiera spp. ${ }^{3} \mathrm{HC}$ : heterocystous cyanobacteria, NHC: non-heterocystous cyanobacteria

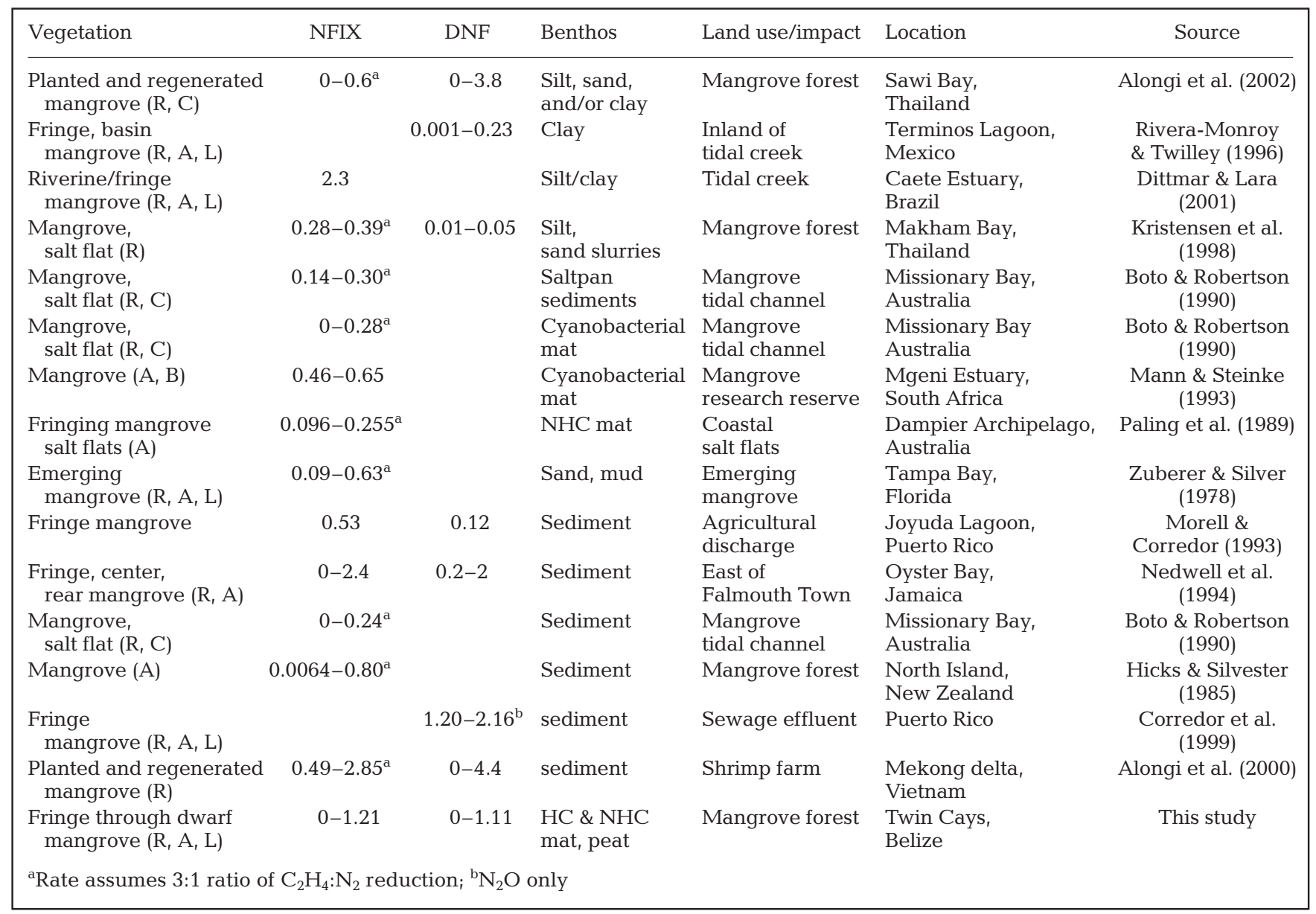


mangrove environments were broadly related to $\mathrm{NO}_{3}{ }^{-}$ inputs associated with land use, such as agriculture, industry, sewage and shrimp-farming (Corredor et al. 1999, Alongi et al. 2000, 2002), which suggests that mangrove mats, particularly those in fringe and transition habitats, may naturally mitigate anthropogenic DIN inputs. Efforts aimed at conservation and restoration of mangrove forests should consider microbial processes such as those observed in cyanobacterial mats and soils (Holguin et al. 2001, Rejmánková et al. 2004), as these processes may influence the productivity and potential recovery of mangrove habitats.

Acknowledgements. We thank W. Porubsky for assistance in the field and laboratory, Dr. S. Golubic for aid with cyanobacterial identification, Drs. R. Twilley and I. C. Feller for insightful discussion, the Smithsonian Institution's Carrie Bow Cay Field Station staff and M. Carpenter for logistical assistance, and 2 anonymous reviewers for constructive comments that improved this manuscript. This work was supported by the U.S. NSF's Biocomplexity in the Environment Program (award DEB-0002796 to S. B. J. and DEB-9981535 to Dr. I. C. Feller).

\section{LITERATURE CITED}

Alongi DM, Tirendi F, Trott LA, Xuan TT (2000) Benthic decomposition rates and pathways in plantations of the mangrove Rhizophora apiculata in the Mekong delta, Vietnam. Mar Ecol Prog Ser 194:87-101

Alongi DM, Trott LA, Wattayakorn G, Clough BF (2002) Below-ground nitrogen cycling in relation to net canopy production in mangrove forests of southern Thailand. Mar Biol 140:855-864

Álvarez-Salgado XA, Miller AEJ (1998) Simultaneous determination of dissolved organic carbon and total dissolved nitrogen in seawater by high temperature catalytic oxidation: conditions for precise shipboard measurements. Mar Chem 62:325-333

Atlas RM (1995) Handbook of media for environmental microbiology. CRC, Boca Raton, FL

Bebout BM, Fitzpatrick MW, Paerl HW (1993) Identification of the sources of energy for nitrogen fixation and physiological characterization of nitrogen-fixing members of a marine microbial mat community. Appl Environ Microbiol 59:1495-1503

Boto KG, Robertson AI (1990) The relationship between nitrogen fixation and tidal exports of nitrogen in a tropical mangrove system. Estuar Coast Shelf Sci 31:531-540

Capone DG (1988) Benthic nitrogen fixation. In: Blackburn $\mathrm{TH}$, Sørensen J (eds) Nitrogen cycling in coastal marine environments. John Wiley \& Sons, New York, p 85-123

Cline JD (1969) Spectrophotometric determination of hydrogen sulfide in natural waters. Limnol Oceanogr 14:454-458

Corredor JE, Morell JM, Bauza J (1999) Atmospheric nitrous oxide fluxes from mangrove sediments. Mar Poll Bull 38: 473-478

Diaz MC, Ward BB (1997) Sponge-mediated nitrification in tropical benthic communities. Mar Ecol Prog Ser 156:97-107

Dittmar T, Lara RJ (2001) Driving forces behind nutrient and organic matter dynamics in a mangrove tidal creek in north brazil. Estuar Coast Shelf Sci 52:249-259

Feller IC (1996) Effects of nutrient enrichment on leaf anatomy of dwarf Rhizophora mangle L. (red mangrove) Biotropica 28:13-22

Feller IC, McKee KL, Whigham DF, O'Neill JP (2003) Nitrogen vs. phosphorus limitation across an ecotonal gradient in a mangrove forest. Biogeochemistry 62:145-175

Hicks BJ, Silvester WB (1985) Nitrogen fixation associated with the New Zealand mangrove (Avicennia marina (Forsk.) Vierh. var. resinifera (Forst. f.) Bakh.) Appl Environ Microbiol 49:955-959

Holguin G, Vazquez P, Bashan Y (2001) The role of sediment microorganisms in the productivity, conservation, and rehabilitation of mangrove ecosystems: an overview. Biol Fertil Soils 33:265-278

Horne AJ, Commins ML (1987) Macronutrient controls on nitrogen fixation in planktonic cyanobacteria populations. NZ J Mar Freshw Res 21:413-423

Howarth RW (1988) Nutrient limitation of net primary production in marine ecosystems. Ann Rev Ecol 19:89-110

Joye SB, Hollibaugh JT (1995) Influence of sulfide inhibition of nitrification on nitrogen regeneration in sediments. Science 270:623-625

Joye SB, Lee RY (2004) Benthic microbial mats: important sources of fixed nitrogen and carbon to the Twin Cays, Belize ecosystem. Atoll Res Bull 528:1-26

Joye SB, Paerl HW (1994) Nitrogen cycling in microbial mats: rates and patterns of denitrification and nitrogen fixation. Mar Biol 119:285-295

Kristensen E, Jensen MH, Banta GT, Hansen K, Holmer M, King GM (1998) Transformation and transport of inorganic nitrogen in sediments of a southeast Asian mangrove forest. Aquat Microb Ecol 15:165-175

Lidstrom ME (1988) Isolation and characterization of marine methanotrophs. Antonie van Leeuwenhoek 54:189-199

MacKay NA, Elser JJ (1998) Nutrient cycling by Daphnia reduces $\mathrm{N}_{2}$ fixation by cyanobacteria. Limnol Oceanogr 43:347-354

Mann FD, Steinke TD (1993) Biological nitrogen fixation (acetylene reduction) associated with blue-green algal (cyanobacterial) communities in the Beachwood Mangrove Nature Reserve II: seasonal variation in acetylene reduction activity. S Afr J Bot 59:1-8

McKee KL, Feller IC, Popp M, Wanek W (2002) Mangrove isotopic $\left(\delta^{15} \mathrm{~N}\right.$ and $\left.\delta^{13} \mathrm{C}\right)$ fractionation across a nitrogen vs. phosphorus limitation gradient. Ecology 83: 1065-1075

Morell JM, Corredor JE (1993) Sediment nitrogen trapping in a mangrove lagoon. Estuar Coast Shelf Sci 37:203-212

Nedwell DB, Blackburn TH, Wiebe WJ (1994) Dynamic nature of the turnover of organic carbon, nitrogen and sulphur in the sediments of a Jamaican mangrove forest. Mar Ecol Prog Ser 110:223-231

Paerl HW (1990) Physiological ecology and regulation of $\mathrm{N}_{2}$ fixation in natural waters. Adv Microb Ecol 11:305-344

Paerl HW, Pinckney JL (1996) A mini-review of microbial consortia: their roles in aquatic production and biogeochemical cycling. Microb Ecol 31:225-247

Paerl HW, Crocker KM, Prufert LE (1987) Limitation of $\mathrm{N}_{2}$ fixation in coastal marine waters: relative importance of molybdenum, iron, phosphorus, and organic matter availability. Limnol Oceanogr 32:525-536

Paerl HW, Bebout BM, Prufert LE (1989) Naturally occurring patterns of oxygenic photosynthesis and $\mathrm{N}_{2}$ fixation in a marine microbial mat: physiological and ecological ramifications. In: Cohen Y, Rosenberg E (eds) Microbial mats. American Society for Microbiology, Washington, DC, p 326-341

Paerl HW, Joye SB, Fitzpatrick M (1993) Evaluation of nutri- 
ent limitation of $\mathrm{CO}_{2}$ and $\mathrm{N}_{2}$ fixation in marine microbial mats. Mar Ecol Prog Ser 101:297-306

Paling EI, McComb AJ (1994) Cyanobacterial mats: a possible nitrogen source for arid-coast mangroves. Int $\mathrm{J}$ Ecol Environ Sci 20:47-54

Paling EI, McComb AJ, Pate JS (1989) Nitrogen fixation (acetylene reduction) in nonheterocystous cyanobacterial mats from the Dampier Archipelago, Western Australia. Aust J Mar Freshw Res 40:147-153

Pinckney J, Paerl HW, Fitzpatrick M (1995) Impacts of seasonality and nutrients on microbial mat community structure and function. Mar Ecol Prog Ser 123:207-216

Postgate JR (1982) The fundamentals of nitrogen fixation. Cambridge University, London

Potts M (1980) Blue-green algae (Cyanophyta) in marine coastal environments of the Sinai Peninsula: distribution, zonation, stratification and taxonomic diversity. Phycologia 19:60-73

Potts M (1999) Mechanisms of desiccation tolerance in cyanobacteria. Eur J Phycol 34:319-328

Rejmánková E, Komárek J, Komárková J (2004) Cyanobacteria - a neglected component of biodiversity: patterns of species diversity in inland marshes of northern Belize (Central America). Diversity Distrib 10:189-199

Rivera-Monroy VH, Twilley RR (1996) The relative role of denitrification and immobilization in the fate of inorganic nitrogen in mangrove sediments (Terminos Lagoon, Mexico). Limnol Oceanogr 41:284-296

Rodriguez W, Feller IC (2004) Mangrove landscape characterization and change in Twin Cays, Belize, using aerial photography and IKONOS satellite data. Atoll Res Bull 513:1-24

Editorial responsibility: Victor de Jonge (Contributing Editor), Haren, The Netherlands
Solorzano L (1969) Determination of ammonia in natural waters by the phenolhypochlorite method. Limnol Oceanogr 14:799-801

Solorzano L, Sharp JH (1980) Determination of total dissolved phosphorus and particulate phosphorus in natural waters. Limnol Oceanogr 25:754-758

Sorensen J, Tiedje JM, Firestone RB (1980) Inhibition by sulfide of nitric and nitrous oxide reduction by denitrifying Pseudomonas fluorescens. Appl Environ Microbiol 39:105-108

Stal LJ (1995) Physiological ecology of cyanobacteria in microbial mats and other communities. New Phytol 131:1-32

Stal LJ (2000) Cyanobacterial mats and stromatolites. In: Whitton BA, Potts M (eds) The ecology of cyanobacteria. Kluwer Academic, Dordrecht, p 61-120

Stookey LL (1970) Ferrozine-A new spectrophotometric reagent for iron. Anal Chem 42:779-781

Strickland JDH, Parsons TR (1972) A practical handbook of seawater analysis. Bull Fish Res Board Can, Ottawa

Tam TY, Mayfield CI, Inniss WE, Knowles R (1982) Effect of sulfide on nitrogen fixation in a stream sediment-water system. Appl Environ Microbiol 43:1076-1079

Valiente EF, Queseda A, Prosperi C, Nieva M, Leganes F, Ucha A (1997) Short- and long-term effects of ammonium on photodependent nitrogen fixation in wetland rice fields of Spain. Biol Fertil Soils 24:353-357

Villbrandt M, Stal LJ (1996) The effect of sulfide on nitrogen fixation in heterocystous and non-heterocystous cyanobacterial mat communities. Arch Hydrobiol Suppl Algol Stud 83:549-563

Zuberer DA, Silver WS (1978) Biological dinitrogen fixation (acetylene reduction) associated with Florida mangroves. Appl Environ Microbiol 35:567-575

Submitted: February 22, 2005; Accepted:July 27, 2005

Proofs received from author(s): December 19, 2005 